NBER WORKING PAPER SERIES

A NEW FINANCIAL ORDER IN ASIA:

WILL A RMB BLOC EMERGE?

Takatoshi Ito

Working Paper 22755

http://www.nber.org/papers/w22755

\author{
NATIONAL BUREAU OF ECONOMIC RESEARCH \\ 1050 Massachusetts Avenue \\ Cambridge, MA 02138 \\ October 2016
}

An earlier draft was written and presented in a conference at the University of Tokyo on July 25-26, 2016. The author is grateful to participants of the conference. The first author acknowledges financial support Japan's Grant-in-Aid for Scientific Research A-25245044. The views expressed herein are those of the author and do not necessarily reflect the views of the National Bureau of Economic Research.

NBER working papers are circulated for discussion and comment purposes. They have not been peer-reviewed or been subject to the review by the NBER Board of Directors that accompanies official NBER publications.

(C) 2016 by Takatoshi Ito. All rights reserved. Short sections of text, not to exceed two paragraphs, may be quoted without explicit permission provided that full credit, including $\odot$ notice, is given to the source. 
A New Financial Order in Asia: Will a RMB bloc emerge?

Takatoshi Ito

NBER Working Paper No. 22755

October 2016

JEL No. E52,F31,F33,F38

\begin{abstract}
$\underline{\text { ABSTRACT }}$
The objective of this paper is three-fold. First, the monetary and exchange rate regimes of the Asian countries are described and analyzed. The degrees of flexibility in exchange rates and capital controls vary across countries. Some countries have adopted a flexible inflation targeting framework, while others have pursued exchange rate targeting. The paper presents a new result of a tradeoff between price stability and exchange rate stability in the hyperbolic relationship of Asian countries. Second, a framework that analyzes and quantifies the degree of currency internationalization is proposed and applied to the RMB. In every indicator, the RMB's weight in private-sector international finance has grown in the last several years, both in the private and public sectors. In the settlement role of currency, the RMB is ranked 8th in the BIS survey and 7th in SWIFT usage. This paper exploits data of a recent period when the RMB became depegged from the USD and show some of the emerging Asian currencies co-moving with the $\mathrm{RMB}$, more so than the USD. In the official sector, RMB is also increasing its weight. The Chinese central bank has extended the currency-swap agreements with 30-some countries, so that the RMB can be used for trade finance and liquidity assistance. The RMB is adopted as a composition currency of the Special Drawing Rights (SDR), effective in October 2016, with 10.92 percent, ranking number 3, surpassing the JPY and GBP. Finally, potential impending changes in the Asian monetary and exchange rate regimes in Asia are discussed. Projecting the growth of the Chinese economy into the future, the weight of the RMB in the financial markets will increase globally as well as in Asia.
\end{abstract}

Takatoshi Ito

Columbia University

School of International and Public Affairs

International Affairs Building

Room 927, (MC 3333)

420 West 118th Street

New York, NY 10027

and NBER

ti2164@columbia.edu 


\title{
A New Financial Order in Asia: \\ Will a RMB bloc emerge?
}

Takatoshi Ito ${ }^{1}$

October 10, 2016

\begin{abstract}
The objective of this paper is three-fold. First, the monetary and exchange rate regimes of the Asian countries are described and analyzed. The degrees of flexibility in exchange rates and capital controls vary across countries. Some countries have adopted a flexible inflation targeting framework, while others have pursued exchange rate targeting. The paper presents a new result of a tradeoff between price stability and exchange rate stability in the hyperbolic relationship of Asian countries. Second, a framework that analyzes and quantifies the degree of currency internationalization is proposed and applied to the RMB. In every indicator, the RMB's weight in private-sector international finance has grown in the last several years, both in the private and public sectors. In the settlement role of currency, the RMB is ranked $8^{\text {th }}$ in the BIS survey and $7^{\text {th }}$ in SWIFT usage. This paper exploits data of a recent period when the RMB became de-pegged from the USD and show some of the emerging Asian currencies co-moving with the RMB, more so than the USD. In the official sector, RMB is also increasing its weight. The Chinese central bank has extended the currency-swap agreements with 30-some countries, so that the RMB can be used for trade finance and liquidity assistance. The RMB is adopted as a composition currency of the Special Drawing Rights (SDR), effective in October 2016, with 10.92 percent, ranking number 3, surpassing the JPY and GBP. Finally, potential impending changes in the Asian monetary and exchange rate regimes in Asia are discussed. Projecting the growth of the Chinese economy into the future, the weight of the RMB in the financial markets will increase globally as well as in Asia.
\end{abstract}

Key words: Asia, financial architecture, self-insurance, Chiang Mai Initiative (CMI), Renminbi internationalization, Special Drawing Right (SDR), central bank currency swap, Frankel-Wei regression

JEL: E52, F31, F33, F38,

1 Professor, School of International and Public Affairs, Columbia University. Email: ti2164@columbia.edu. An earlier draft was written and presented in a conference at the University of Tokyo on July $25-26,2016$. The author is grateful to participants of the conference. 


\section{Introduction}

The objective of this paper is three-fold. First, the paper shows that, despite some efforts toward close financial cooperation in Asia since the Asian Currency Crisis (AFC), the regional financial regimes remain diverse. Since the AFC of 1997-98, Asian countries (mostly ASEAN plus China, Japan, and Korea) have become resilient to external shocks by adopting a managed exchange rate regime and maintaining capital controls. The degrees of flexibility in exchange rates and capital controls vary across countries. Some countries have adopted a flexible inflation targeting framework, while others have pursued exchange rate targeting. Diverse monetary and exchange rate regimes coexist and prevent closer financial cooperation beyond an incomplete, untested safety net - namely the Chiang Mai Initiative (CMI), established in 2000, and its evolved version, CMIMultilateralization. A proposal for a common basket currency unit did not gain popularity. Thus, a regional financial architecture did not emerge. Substantial increases in foreign reserves since 2000 have made Asian emerging market economies robust against sudden capital outflows. Some countries effectively used foreign reserves to mitigate the exchange rate volatility. Building up foreign reserves and using them (self-insurance) have worked in Asia.

Second, progress in the Chinese government effort toward the RMB internationalization is reviewed and assessed. After the Global Financial Crisis (GFC) of 2008-09, China has pushed and succeeded in internationalizing the RMB. The ranking of $\mathrm{RMB}$ usage has risen in every measure of internationalized currency. In particular, the Asian currencies co-move more with the RMB than the USD; The Chinese central bank has extended the currency-swap agreements with 30-some countries, so that RMB can be used for trade finance and liquidity assistance. All these efforts led to wider use of the RMB, which helped the International Monetary Fund (IMF)'s decision to include RMB in the SDR composition, effective on October 1, 2016. The RMB weight in SDR is determined to be higher than JPY and GBP, mainly reflecting a larger share in global trade.

Third, in projecting the growth of the Chinese economy relative to advanced countries, the weight of RMB in the financial markets will increase globally as well as regionally in the foreseeable future. Combining the RMB internationalization with other initiatives that the Chinese government is making in the area of development assistance such as the Asian Infrastructure Investment Bank (AIIB) and One Belt One Road, the RMB may have the chance to become a regional reserve currency, such as the Euro, if not a global one.

\section{Asian Currency Crisis and its aftermath}

Prior to the Asian currency crisis of 1997-98, the Asian emerging market and 
developing economies had a (de facto) dollar peg. As they slowly open their capital accounts, some countries faced two problems. First, domestic monetary policy could not autonomously aim at the domestic objectives as capital inflows started to overheat the economy. Either the fixed exchange rate regime or autonomous monetary policy had to be abandoned if capital flows were to be allowed more freely in and out of the country. In short, countries like Thailand and Malaysia, by pursuing financial liberalization, fell into the impossible trinity trap. Moreover, commercial banks were borrowing from abroad in short-term dollar funding and lending long to domestic borrowers in the local currency. The double mismatch made those banks vulnerable to future shocks, such as currency devaluation. With the benefit of hindsight, it was foretold that a banking crisis would follow the currency crisis.

The Asian currency crisis of 1997-98 affected almost the entire Asian region, with the notable exception of China, where strict capital controls protected the economy from spillovers. (See Ito (2007) for a detailed analysis of the Asian financial crisis.) The origin of the Asian crisis was in Thailand, where large capital inflows had exceeded large trade deficits ( $8 \%$ of GDP), thus increasing foreign reserves, which gave a false sense of security. The economy boomed in 1993-95. A sudden depreciation on July 2, 1997 in Thailand was caused by unsustainable macroeconomic policy, with speculative attacks earlier in the year making the damage larger.

All of the Southeast Asian emerging market economies and Korea suffered sudden and large depreciations in the second half of 1997. Indonesia suffered the largest depreciation and GDP decline. Depreciation made the banks suffer from balance sheet problems, both from currency mismatches and nonperforming loans problem of corporations. Indonesia also suffered high inflation despite a large GDP gap, since monetary policy accommodated the inflationary pressure. Other countries did not experience high inflation due to a large decline in output.

The IMF assistance was extended to Thailand in August, Indonesia in November and Korea in December. The IMF involvement, which was supposed to made the damage less and prevent contagion, did not work well. The IMF program for Thailand was too small to stabilize the exchange rate (Ito (2007)), and depreciation of the baht continued. The IMF program for Korea and Indonesia contained structural policy as well as macroeconomic policy as conditionality. The closure of sixteen banks as a "prior actions" of the Indonesia program of November made the crisis worse by causing a bank run. A long list of structural reforms that was signed by IMF Managing Director Michel Camdessus and Indonesian President Suharto did not impress the market.

When the worst of the Asian crisis was over, efforts to make the crisis-hit economies 
robust in the future had begun. The three IMF-program countries adopted the floating exchange rate regimes. This made it possible to assign monetary policy to domestic objectives, that is, price stability and full employment. Later, all the three IMF-program countries, as well as the Philippines, would adopt the inflation targeting framework. Capital controls were gradually removed, but they maintained some controls to prevent currency speculation.

Among the ASEAN+3 countries and other regional economies (Hong Kong and Taiwan) have very diverse monetary and exchange rate regimes. The exchange rate regimes span from the hard peg (Hong Kong) to the free float (Japan). In some countries, monetary policy is secondary to the exchange rate policy, while others have an inflation targeting framework. This diversity means that monetary cooperation in the region is almost impossible, and an external shock (originating outside Asia) may produce a large change in the intra-regional cross rates (such as the Japanese yen/Korean won rate).

After the Asian crisis, all countries tried to address the problem of the "double mismatch" in the financial system. The crucial part is to encourage Asian countriessovereign and corporate - to issue long-local local-currency bonds. The Asian Bond Initiative centered at the Asian Development Bank was a collection of efforts to address obstacles in efforts by individual countries. One of the obstacles was a lack of a credit ratings standard across countries. An organization to coordinate national credit rating agencies was created.

Unfamiliarity and the perceived high risk of local-currency bonds of Asian countries was also a problem in promoting those bonds. The Hong Kong monetary authority took the initiative to create a fund of bundled local-currency government bonds, Asian bond Fund II, and enabled it to be traded in the stock exchange. However, there was no sequel to it.

Even if a country or banks are solvent (assets exceeding liabilities), it may fall into a crisis if the liquidity is lacking (assets cannot be liquidated at market prices to pay for massive withdrawals). Liquidity assistance, or safety net, was supposed to be provided by the IMF in the event of a currency crisis. However, during the Asian currency crisis of 1997-98, the IMF assistance fell short of stopping the crisis or its contagion.

In the post-crisis period, Asian countries worked on developing a mutual liquidity assistance network, the Chiang Mai Initiative (CMI), which was agreed upon in May 2000. However, initially only $10 \%$ of the swap amount could be provided without an IMF program (90\% IMF linkage). Thus, it was only a supplementary fund for the IMF program. The size and ratio of IMF linkage were improved over time. In 2010, the network of bilaterals was replaced by a pool of ear-marked foreign reserves. It is now called Chiang 
Mai Initiative Multilateralization (CMIM). The IMF linkage has been lowered to $70 \%$. However, CMI or CMIM has not been tested.

Most Asian countries have increased the size of their foreign reserves (absolute amount, in ratio to imports, and the ratio to GDP) since 2000, beyond just replenishing to their pre-crisis levels. The bigger the buffer for capital outflows, the better, they argue. This is called self-insurance. They were willing to pay for the interest rate difference between the foreign securities as assets and the domestic securities as liabilities. During the GFC, some Asian countries (such as Korea) that faced capital outflows dipped into foreign reserves to mitigate capital outflow pressure.

\section{Diverse Monetary and Forex Regimes in Asia}

Asian countries and economies learned their lessons from the Asian Financial Crisis (AFC) of 1997-98; they reformed their monetary and exchange rate policies and built regional institutions to prevent future crises. So far the efforts have proved to be sufficient. However, they have not moved toward financial integration and closer financial cooperation, a la the Euro zone. The exchange rate regime and monetary policy regimes remain diverse.

Each country that was affected by the AFC made macroeconomic reforms so that the same type of crisis would not happen. The impossible trinity-a set of fixed exchange rates, free capital mobility, and autonomous monetary policy — was avoided as reforms took place. Many Asian countries and economies, except China, Hong Kong, and Brunei, have added exchange rate flexibility after the Asian currency crisis. Hong Kong, as more of an exception, has maintained their dollar peg and open capital market, so their monetary policy is subject to the US Federal Reserve. Brunei, another exception, has maintained the peg to the Singaporean dollar, so that there is no autonomous monetary policy.

One possible danger of adopting a flexible exchange rate regime is to lose monetary discipline, since a nominal anchor is lost. Four countries - Korea, Thailand, Indonesia and the Philippines - have adopted the inflation targeting regime so that the commitment to price stability become explicit. Autonomous monetary policy with an emphasis on domestic objectives - low and stable inflation and full employment-may mean more volatile exchange rate movements, if the economy is hit by external shocks.

Small open economies, such as Singapore, may find it difficult to pursue monetary policy responding to domestic factors only. The exchange rate has a large impact on domestic inflation and output. Singapore formally acknowledged that they seek to stabilize the effective exchange rate, which is the weighted average of bilateral exchange 
rates of the trading partners.

Many Asian emerging economies - mid- and low-income ASEAN members - find it is more practical, reflecting both political and economic realities, to pursue both domestic and external stability.

The four low-income countries in ASEAN — Cambodia, Lao Republic, Myanmar, and Vietnam - have pursued an exchange rate policy to keep the stability of their respective exchange rates vis-à-vis the US dollar. Moreover, large segments of the economies of Cambodia, Lao Republic, and Myanmar are dollarized, so it is difficult for them to pursue any monetary policy. Some countries still rely on resources, while others have successfully industrialized and thrived, and can pursue further industrialization in the footsteps of Japan, Korea, and China. Taipei, China (hereafter Taiwan), and Malaysia have adopted a relatively flexible exchange rate regime, and their monetary policy seems to have sufficient room to pursue inflation targeting, but they have not made the transition.

Volatility in exchange rates, inflation, and output can be reduced if the country maintains capital controls, controlling flows of capital inflows, and outflows. However, that may also hinder industrialization, which is assisted by foreign direct investment with technological transfers. Countries with low savings rates also benefit from portfolio capital inflows as well as foreign direct investment. Thus, low-income to middle-income countries tend to start opening up their capital markets to foreigners. One pitfall is the familiar problem of the impossible trinity. A crisis is likely to happen if a country tries to lift capital controls while maintaining their (near) fixed exchange rate and pursuing autonomous monetary policy with the interest rate being widely different from that of the United States (if the exchange rate is being fixed to the US dollar). This is exactly what happened to several Asian countries, most prominently in Thailand and Korea in 1997.

Even at present, Asian countries and economies vary in their management of capital flows. Japan, Hong Kong, and Singapore are the most open, while some low-income ASEAN countries have maintained moderate-to-strict capital controls. It is difficult to calculate a single number of the degree of openness, as capital flows have many types and practical barriers may be different from letters of the law. However, some researchers have attempted to condense diverse dimensions of capital controls into a single dimension that represents the degree of capital controls.

Fernandez (2015, Table 2), following Klein (2012), categorize countries into three groups in terms of the severity of capital controls: Wall, Gate, and Open. The open countries include Japan, Korea, Hong Kong, Singapore and Brunei qualify. Countries with some but not severe controls are called "Wall" countries that include Indonesia, Thailand, Myanmar and Vietnam. Countries that have severe controls are called countries 
with "Gate," to which China, Malaysia and the Philippines belong. Taiwan is judged to be a "Gate" country by the author of this paper, after interpreting the description on capital flows.

Another popular index for capital controls is the Chinn-Ito openness index, as proposed by Chinn and Ito (2008). The index has been updated to 2014 (see Chinn-Ito (2016)). The index is a numeric number between 0 (not open) to 1 (open). Although the number can be continuous, differences between countries seem to be discrete. The openness for a country changes every year for each country, reflecting changes in regulations and practices. The ranking of the Chinn-Ito index for the year 2014 broadly agrees with the IMF three categories, with a few differences. On a few occasions, the Chinn-Ito index disagrees with the IMF three groups-Open, Gate and Wall in four countries. Suppose that we categorize those countries with the Chinn-Ito index of $0.7-$ 1.0 as "Open"; $0.4-0.7$ as "Gate" and " $0.0-4.0$ " Wall. Then, Thailand, according to the Chinn-Ito index, should be in the "Wall" category rather than "Gate"; Malaysia and the Philippines should be in the "Gate" category rather than "Wall" and Myanmar should be in the "Wall" category rather than "Gate."

Table 1 summarizes the exchange rate regime, monetary policy regime, and the degree of capital controls (two measures), as described above. Two observations emerge from this table. First, Asian countries and economies have very diverse exchange rate regimes and monetary policy frameworks, as well as openness to capital flows. Second, the middle-income emerging market economies tend to maintain a combination of the managed exchange rate regime with moderate capital controls. This allows them to conduct flexible monetary policy pursuing price stability, with or without declaring the inflation targeting framework.

$<$ Table 1 about here $>$

The diversity in these monetary and financial arrangements mean that it would be difficult for the region to cooperate and cope with a large external shock. For example, a sharp price increase (or decrease) in energy prices will have different pressures on various Asian countries. Some currency appreciate while others depreciation. Large financial shocks in the US or Europe also tend to produce opposite movements among the Asian countries. For example, the collapse of Lehman Brothers caused an appreciation of the Japanese yen, which is regarded as a safe haven currency, and a depreciation of the Korean won, which is still in the category of emerging market economy currencies. Thus, the diversity makes it difficult for Asian countries to pursue policy coordination, not to mention efforts toward a common currency, a la the Euro zone. 


\section{Tradeoff between price and exchange rate volatility}

Some Asian countries emphasize price stability, adopting inflation targeting, while others place a higher priority on exchange rate stability. We expect that those countries that pursue price stability tend to suffer from exchange rate volatility, and those countries that pursue exchange rate stability - most notably Hong Kong adopting the fixed exchange rate - tend to suffer deviation from the stable inflation rate.

Let us denote the deviation of the CPI inflation rate $(\pi)$ from the trend (12 month moving average) by $\mathrm{V} \pi$.

$$
\mathrm{V} \pi(\mathrm{t})=\pi(\mathrm{t})-\pi^{m a 12}(t)
$$

Where $\pi^{m a 12}=\frac{\sum_{j=1}^{12} \pi(t-j)}{12}$

Let us denote the absolute change of the nominal bilateral exchange rate vis-à-vis US dollar by $s(t)$. Then the absolute change in the exchange rate is defined as

$$
\mathrm{Vs}=|\mathrm{s}(\mathrm{t})-\mathrm{s}(\mathrm{t}-1)|
$$

The period average of monthly $\mathrm{V} \pi$ and $\mathrm{Vs}$ for each county is calculated. We use data after January 2000, and for the sample period starting at January 2001 (as we lose the first 12 months for calculating the moving average). Our data end at May 2016. Four subperiods are selected to match changes in the Chinese exchange rate policy.

China kept the fixed exchange rate regime until July 20, 2005. The People's Bank of China introduced a one-time appreciation on July 21, 2005 and moved to a crawling peg-gradual appreciation - until July 2008, when, in light of turbulent international financial markets due to the subprime crisis, China effectively fixed the exchange rate again to the US dollar. The crawling peg resumed at around July 2008. The flexibility in both directions turned out to be higher in the subsequent period. Therefore the following four sub-periods are identified:

$\begin{array}{lll}\text { I. } & \text { Jan 2001 - June 2005 } & \text { Fixed } \\ \text { II. } & \text { July 2005- June 2008 } & \text { Crawling Peg } \\ \text { III. } & \text { July 2008 - June 2010 } & \text { Fixed (during GFC) } \\ \text { IV. } & \text { July 2010- May 2016 } & \text { Managed Float }\end{array}$

Figure 1 shows the daily movement of the RMB as described above.

\section{$<$ Figure 1>}

The horizontal axis is for the period average of $\mathrm{V} \pi$ for country $\mathrm{k}, \mathrm{V} \pi_{j, k}$ and the vertical axis is for the period average of the exchange rate volatility for country $k$, $\mathrm{Vs}_{j, k}$. where $\mathrm{j}=\mathrm{I}$, II, III, IV, as defined above. Suppose a country wishes and can adhere to achieve the inflation target; the combination of measures of the price stability and the exchange rate stability for country $\mathrm{k}$ should move vertically. Suppose a country is 
adopting the fixed exchange rate; then the combination of measures of the price stability and the exchange rate stability for country $\mathrm{k}$ should move horizontally.

Figure 2 shows plots of $\left(\mathrm{V} \pi_{j, k}, \mathrm{Vs}_{j, k}\right)$ for Asian countries (excluding Cambodia, Myanmar, Lao). Since theories predict price targeters lining up near the vertical axis and exchange rate targeters lining up near the horizontal axis, a linear regression would not fit the tradeoff between the two stability indicators. A hyperbola is estimated to show the relationship between the price stability and the exchange rate stability.

$<$ Figure $2>$

The hyperbola $\mathrm{Vs}_{j, k}=\frac{c}{\mathrm{~V} \pi_{j, k}}$ is estimated with the following regression:

$$
\log \left(\mathrm{Vs}_{j, k}\right)=-0.872+\log \left(\mathrm{V} \pi_{j, k}\right)
$$

Where the number in the bracket shows the standard error. The constant is statistically significant at 5 percent (with the P-value being 0.026).

The original coefficient $\mathrm{c}$ can be recovered as $\mathrm{c}=\exp (-0.872)=0.417965$.

The hyperbola line is added to Figure 2. A tradeoff exists between price targeting with a floating exchange rate and the exchange rate stability with inflation rate volatility. The hyperbola shows such a tradeoff.

In Figure 2, most countries are near the hyperbola line, and there are a few countries that markedly deviate from the line. The Hong Kong and China dots are below (southwest of) the hyperbola line. Namely, the two economies had less volatile inflation and less volatile exchange rates. But, the reasons may be totally different. It is natural that Hong Kong, having a hard peg to the US dollar, has minimal exchange rate volatility. Inflation stability, less than that of other countries, is partly due to its policy of following US monetary policy, which targets price stability successfully. As explained above, Hong Kong is an exception in abandoning an autonomous monetary policy, with capital markets being completely open and the exchange rate completely fixed. China is a different case, although the exchange rate stability - fixed in Periods I and III, and crawling peg in other periods - is their policy choice. Since capital controls are still in place, China could exercise autonomous monetary policy. However, the Chinese inflation rate turned out to be much more stable than other countries with similar exchange rate stability. Capital controls helped prevent portfolio capital inflows that would have driven the economy toward overheating, given its phenomenally high growth rate.

There are a few countries that are above (northeast of) the hyperbola line. Indonesia experienced more volatility in its inflation and exchange rates than other countries. In addition, during the GFC (Period III), many countries had large deviations from the 
hyperbola line: Malaysia, Singapore, Korea, Japan, Thailand, Vietnam, and the Philippines.

The tradeoff discussed in this section is between two entities in the "impossible trinity." It is conceivable to frame the analysis to consider a tradeoff between the three factors. Indeed, Aizenman, and Ito (2014) explicitly consider the deviation from the three criteria, i.e., free floating, monetary autonomy index, and free capital mobility. The exchange rate volatility in their paper is similar to mine in this paper. Their monetary autonomy index uses the interest rate deviation from "the base country," while our definition in this paper uses the result of monetary policy, namely the inflation rate.

Capital controls are not explicitly in the consideration of the paper, unlike Aizenman and Ito (2014). Many emerging market economies try to liberalize in the medium run if they think they can manage large capital inflow and outflows, which may increase the exchange rate volatility. ${ }^{2}$ Capital controls are not considered to be a necessary complement to a set of the fixed exchange rate and the autonomous monetary policy, but an instrument to manage the exchange rate volatility.

In sum, the monetary arrangements among Asian countries and economies are very diverse. A regional cooperation in monetary policy or the exchange rate policy would be very difficult unless some countries shift their policy frameworks.

\section{Safety Net}

\subsection{Chiang Mai Initiative}

During the AFC, crisis-affected Asian countries felt the foreign reserves that had been accumulated were not enough to avoid a capital-account crisis in the first place and the IMF assistance was too small to prevent a worsening of the crisis once it started. The ratio of foreign reserves to short-term liability was less than 1 in Thailand, Indonesia, and Korea. The relative lack of foreign reserves made the crisis more likely. The IMF is supposed to provide liquidity while necessary macroeconomic reforms are conducted. However, during the Asian crisis, the IMF was blamed for its misguided reform agenda and for an insufficient rescue package (Ito (2007)). Asian countries are still afraid of insufficient foreign reserves and the possibility of asking the IMF for advice and liquidity. The origin of Asian self-insurance is the IMF stigma (Ito (2012)).

In response to the limitation of the IMF, Asian countries tried to develop their own mutual assistance institution. Japan and some ASEAN countries floated the idea of a reserve pooling mechanism at the end of August 1997, which was dubbed as the Asian

\footnotetext{
2 Aizenman and Pasricha (2013) examined why emerging market countries liberalize capital outflows.
} 
Monetary Fund. This initiative followed the rescue package for Thailand that was engineered by Japan and the IMF, but before the contagion would spread to Indonesia and Korea. The AMF idea was abandoned after the US and the IMF opposed it strongly and China did not support it either in the IMF annual meeting in Hong Kong in September. Efforts to build a mechanism that is acceptable to the US and the IMF was renewed after the Indonesian and Korean crises exposed the limitation of the IMF's assistance in size and conditions. In May, the ASEAN plus 3 (ASEAN, Japan, China, and Korea) agreed to building a mechanism that is based on bilateral currency swaps. The bilateral swaps network became known as the Chiang Mai Initiative (CMI). In the original framework of CMI, each of the plus-3 countries (Japan, China, and Korea) agreed to a swap agreement for middle-income ASEAN countries. The swap agreement was to provide the plus-3 countries' US dollar reserves in exchange for the ASEAN country's local currency for a period of six months. 10 percent of the agreed total amount would be released when a request was made and granted, but 90 percent would be conditional on an IMF program for a crisis country. Later, the size would be increased and the IMF linkage would be reduced to 70 percent. In addition, ASEAN countries had a mutual assistance mechanism, the ASEAN swap arrangement (ASA). ${ }^{3}$

The CMI was not used at all, and emerging market economies had two concerns about CMI. First, the IMF linkage makes it very difficult politically for those countries with the IMF stigma. Second, a potential recipient of liquidity assistance would have to obtain three bilateral swaps (with Japan, China, and Korea) and ASA had to be approved separately but simultaneously to gain the maximum amount.

In 2010, CMI was reorganized to be CMI-Internationalization (CMI-M), which would unify the trigger for assistance. ${ }^{4}$ The foreign reserves of each participating countries would be ear-marked for the swap agreement. However, CMI-M is not used. See Sussangkarn (2011) for the evolution and details of the CMI and CMI-M.

One concern about the effectiveness of the CMI and the CMI-M is that it has not been tested. No crisis has happened in Asia which requires CMI(-M) to be activated. The first

3 The Monetary Authorities of the original five ASEAN (ASEAN) - Indonesia, Malaysia, Philippines, Singapore, and Thailand - agreed to establish reciprocal currency swap arrangements in August 1977. The ASEAN Swap Arrangement (ASA) was created primarily to provide liquidity support for those experiencing balance of payments difficulties. At the time of launching CMI, ASA was expanded to include all 10 countries of ASEAN. In November 2000, the total amount available for swap transactions under ASA was increased from US $\$ 200$ million to US\$1 billion. In May 2005, during the 8th ASEAN+3 Finance Ministers' Meeting, the total amount for the ASEAN Swap Arrangement was further doubled to US $\$ 2$ billion.

${ }^{4}$ See Sussangkarn (2011) for rivalry between Japan and China in determining quota shares in CMI-M. 
case would be crucial to establish its reputation as a safety net.

\subsection{Self-insurance}

Asian countries are not counting on $\mathrm{CMI}(-\mathrm{M})$ as a safety net. They have attempted to accumulate foreign reserves by themselves. Figure 3 shows foreign reserves of Asian countries, excluding China and Japan. These foreign reserves declined from 1996 to 1997 , reflecting AFC. By 2000, the level of foreign reserves recovered to the pre-crisis trend line. Then came an accelerated accumulation of foreign reserves from 2001 to 2007. This period is the best example of building up foreign reserves as "self-insurance." Then came the GFC. Asian countries that are hit by capital outflows used interventions (loss of foreign reserves) to mitigate the degree of depreciation. This is most prominent in Korea, which reduced their foreign reserves in 2008.

$<$ Figure $3>$

Unlike CMI(-M), which relies on an institutional framework that is not tested, selfinsurance was tested during the GFC. Asian emerging countries were broadly satisfied that their economies were not affected, at least via the financial channel. In most Asian emerging countries, declines in GDP during the GFC of 2008-09 were less than those during the AFC of 1997-98.

Self-insurance seemed to have worked for some countries in Asia. Dominguez, Hashimoto and Ito (2012) proposed a method to estimate intervention amounts from the change in foreign reserves, the interest rate differential, and currency valuation changes. They argued that when faced with capital outflow pressures in the wake of GFC, Asian countries managed the degree of depreciation by intervening to sell US dollars (depleting reserves). They argued that countries with larger reserves had faster recovery after GFC, irrespective of the degree of exchange market pressure (EMP). Aizenman and Hutchison (2012) analyzed the framework of EMP to show that exchange market pressure (EMP) was used to analyze the tradeoff between depreciation and foreign reserve losses in the wake of GFC. They showed that countries with fewer foreign reserves relative to shortterm external portfolio debt prior to a crisis rely more on exchange rate depreciation to absorb the EMP shock.

Aizenman (2011) and Aizenman and Sun (2012) analyzed foreign reserve accumulation and subsequent partial depletion around the GFC, using 21 emerging market data points. They framed a question as a two-stage crisis model with unknown duration, and derived a policy response. They argued that those who accumulated foreign reserves in good times of strong exports spent down foreign reserves in the process of deleveraging. Some countries used foreign reserves to repay short-term external 
borrowings in the first phase of the GFC crisis. However, they found that emerging market economies became reluctant to deplete beyond one-third of the pre-crisis level. Thus Aizenman and Sun argue that emerging market economies were constrained more by fear of losing reserves than by fear of floating. ${ }^{5}$

\subsection{Swap Lines}

The liquidity shortage of the US dollar among financial institutions in the US and in Europe was the most serious aspect of the GFC. ${ }^{6}$ As a sign of liquidity shortage started to show in the summer of 2007, financial institutions attempted to deleverage their balance sheets, namely sell assets and pay back debts. However, as all of the large institutions were eager to sell complex securities, the price plummeted very quickly. They needed dollars to cover their liquidity shortage that emerged from payments to reduce liabilities, which outpaced asset sales. In 2008, the Federal Reserve introduced various facilities to help financial institutions in providing liquidity. However, financial institutions and other corporations in other countries that were required to pay in US dollars had difficulties in obtaining dollar funding as most of international financial transactions were denominated in US dollars.

Concerned with a dollar shortage spreading globally, the Federal Reserve quickly extended currency swaps to other central banks of the advanced countries-first to ECB and Swiss National Bank, starting in December 12, 2007, with modest sizes. The country list and size were quickly expanded in September to include the Bank of England, as well as the central banks of Australia, Canada, Sweden, Denmark, and Norway. In addition, the Federal Reserve took the unprecedented step of extending currency swaps to Korea, Singapore, Mexico, New Zealand, and Brazil in late October 2008. See Goldberg, Kennedy and Miu (2011) for details of these swaps.

Korea and other Asian countries were impressed by the power of currency swaps extended by the Federal Reserve, as a sharp depreciation of the won seemed to be stopped. The swap was viewed by Asian emerging market economies as a quick, unlimited safety net without policy reform conditions. The IMF program and IMF-linked CMI would be available only after intense negotiations with the IMF; the assistance comes with conditionality (policy commitment for various reforms); and the size tends to be limited. The central bank swap extended by the Federal Reserve was preferred by emerging

\footnotetext{
5 Aizenman, Cheung and Ito (2015) examined the self-insurance behavior after GFC, and some factors that explain foreign reserves remained the same while others have changed.

6 The literature on the global financial crisis is now lengthy. For example, see Ito (2010a) as one of the early description of the GFC events and policy responses.
} 
markets in every aspect. If central bank swaps by the Federal Reserve were available during peace time as well as an assurance that it will not be suspended during a crisis time, costly foreign reserve accumulation, or self-insurance, may not be necessary. It was not surprising that Korea asked for an extension of the Federal Reserve swap lines several times until it was terminated in February $2010 .^{7}$ It turned out that the swap arrangements for emerging market economies were exceptional and temporary. On the contrary, central bank swap lines of Federal Reserve with advanced countries (Canada, England, Japan, Switzerland, and ECB) became "standing arrangements" (effective until further notice) in October 2013. Each of the six central banks can provide liquidity in any of six currencies in their respective countries. The differential treatment between emerging markets and advanced countries brings about a concern about moral hazard on the part of emerging market economies. ${ }^{8}$ See also Aizenman and Pasricha (2010) and Aizenman, Jinjarak, and Park (2011). Which country can receive a swap line is totally dependent on the Federal Reserve. Thus, the Federal Reserve swap line cannot be a reliable safety net for most emerging market economies. ${ }^{9}$

\section{Chinese Challenge to the International Financial Architecture}

\subsection{Weakened US as a financial hegemon}

Although the origin of the GFC was the US subprime housing market and associated securities and collateralized debt obligations (CDOs), the US dollar appreciated vis-à-vis the Euro and almost all emerging market currencies, reflecting an increased demand for dollar liquidity by financial institutions in the process of deleveraging. The Japanese yen and the Swiss franc appreciated vis-à-vis the US dollar.

The GFC of 2008-09 had profound political economy impacts as well as economic and financial damages on the Asian countries. In the second half of 2008, several Asian emerging economies, including Korea and Indonesia, experienced sharp depreciation. The Japanese yen appreciated vis-à-vis the US dollar as the US and European central banks introduced large asset purchases while the Bank of Japan did not act. In the summer of 2008, the Chinese authorities suspended orderly appreciation in the crawling peg style,

\footnotetext{
7 The outstanding balance of swaps had been reduced to zero by February 2010. See the Federal Reserve document: https://www.federalreserve.gov/monetarypolicy/clbs_soma_201002.htm.

${ }^{8}$ An additional reason for determining which country to receive a swap line appears to be activities and exposures (branches and subsidiaries) of US financial institutions that need dollar liquidity funding when capital flows reverse direction. After Korea was extended a swap line, Indonesia requested a similar arrangement to the Federal Reserve (according to my private conversation with the Indonesian authority), but the request was not granted.

${ }^{9}$ In November 2010, Korea hosted the G20 meeting. One of the agenda was to build a global "safety net" to cope with a liquidity shortage.
} 
and the yuan was again fixed to the US dollar (see discussion in an earlier section). This was considered by the Chinese authority to contribute to stability in Asia, as occurred during the Asian Financial Crisis.

As a result, intra-regional (cross) exchange rates, such as the Korean won-Japanese yen, moved much more than the bilateral exchange rate vis-à-vis the US dollar. The Korean won depreciated vis-à-vis the Japanese yen by $60 \%$, which contributed to the demise of some of the Japanese consumer electronics companies. Thus, not having a regional financial cooperation was costly to some countries and industries.

China as well as other Asian countries observed the unfolding of the global financial crisis with both disbelief and relief. The disbelief was that the United States, which had been a leader in financial innovation, was the origin of the crisis, and the relief was that the Asian countries were prepared with self-insurance.

\subsection{Benefits}

China was most vocal in arguing that the problem was more fundamental than a failure in US financial institutions. Their view was that the contagion to Europe and Asia was a failure in the international financial system. China would play a role in preventing a further spreading of crisis, by keeping the peg to the US dollar and injecting large fiscal stimulus for economic growth, which was called for at the London G-20 Summit in April 2009. China started to behave like a large country in the international financial architecture.

The subsequent efforts by the Chinese authority to reform the international financial architecture is closely related, or equivalent, to the initiative of "RMB internationalization." Zhou (2009) is commonly credited to be the beginning of the RMB internationalization. In the paper, Zhou argued that the international financial system should be reformed to give a stronger status and the Chinese RMB should be in the SDR basket. (Details of his speech will be discussed in a later section of the paper. See the "SDR" subsection.)

The Chinese monetary authorities must have concluded in the wake of the GFC that the wider international use of the RMB would contribute to both the stability of the international financial system and the economic interest of China in the long run. ${ }^{10}$ The US was taking advantage of, or abusing, the reserve currency status of the US dollar, an exorbitant privilege, and that was a root cause of the GFC. This line of reasoning would lead to a proposal to reinvigorate the super-national reserve currency, with Special Drawing Rights (SDR), as we described above.

${ }^{10}$ Huang and Lynch also think that the GFC is a trigger for the internationalization of the RMB. 
The RMB, as the currency of the second-largest economy, should be a composition currency of SDR. The wider use of RMB also contributes to China's national interest. The Chinese exporters, by reducing the currency risk as importers, would accept invoicing and payments in RMB. If international lending was in RMB, the Chinese monetary authorities could help a crisis country by extending the RMB swap, so that a liquidity crisis may be avoided.

On the development aid front, in October 2013 China proposed a new international organization that is specialized in infrastructure investment in Asia: The Asian Infrastructure Investment Bank (AIIB). Its headquarters would be in Beijing, the President of AIIB would be Chinese, and the size of capital would be $\$ 100$ billion, of which China is prepared to contribute up to 50\%. In April 2015, 57 charter member countries were determined. The United States, Japan, and Canada did not join, while other G7 countries joined in the Bank. The US and Japan voiced concerns about the governance structure: the Board is not resident at the headquarters, so that the executive is powerful; moreover, the quota (capital contribution) is in a two-tier system, which discriminates against non-Asian members like the US, guaranteeing China the highest voting share, with veto power. The AIIB opened its door for business in December 2015. The AIIB has the potential to rival the Asian Development Bank and the World Bank in the Asian region. Many viewed this development as China's challenge to the Bretton-Woods institutions dominated by the United States and the European countries.

However, in order to have the RMB widely used internationally, that is, the RMB being "internationalized," removing capital controls is a necessary step. Hence, the Chinese monetary authority has to have a careful plan and roadmap of internationalization of the RMB.

\section{Internationalization of a currency ${ }^{11}$}

\subsection{Definition}

The roles of an international currency are usually defined as analogous to those of a domestic currency: unit of account (for denomination), medium of exchange (for settlement), and store of value (for saving). It is also useful to distinguish how it is used in the private sector and the official sector, which includes the central bank and the Treasury (Ministry of Finance). Table 2 shows a 3 by 2 matrix with the three roles and two sectors, which was first proposed by Cohen (1971) in the context of the British Pound vs. the US dollar; then popularized by Kenen (1983). This was then applied to the Chinese

11 This section and the next section draw heavily from an unpublished working paper, Ito (2011). 
internationalization context by Ito (2011). ${ }^{12}$

\section{$<$ Table 2>}

The international currency is a currency that has high usage in each of the six cells of the matrix of the table. Kenen (2009) defined international currency in the following way: "An international currency is one that is used and held beyond the borders of the issuing country, not merely for transactions with that country's residents, but also, and importantly, for transactions between non-residents."

The internationalization of the RMB has been discussed by many, including Genberg (2009), Park and Shin (2009), Ito (2011), and Aizenman (2015) to name a few. However, reality moves quite fast. Below is the comprehensive state of RMB internationalization as of summer 2016. ${ }^{13}$ The Euro is considered to be an international currency as it was created (see Moss (2009)).

\subsection{Private-use Unit of Account}

When goods are exported, export contracts have to specify the price of goods in a specified currency. If a car is exported from Japan to France, it is typically denominated in Japanese yen or the euro. Whether the goods price is denominated in the exporter's currency or importer's currency depends on the negotiation power of the two sides as well as the international standing of the two currencies. There are a few "stylized facts" on invoice currencies (Ito, et al. (2012)). ${ }^{14}$ (1) Trade of manufactured products between advanced countries tends to be invoiced in the exporter's currency, which is known as “Grassman's Law" (Grassman, 1973, 1976); (2) Trade of manufactured products between advanced and developing countries tends to be invoiced in the advanced country's currency or, to a lesser extent, in a major international currency such as the US dollar (Grassman, 1973; Page, 1977, 1981); and (3) Differentiated products such as machinery products tend to be invoiced in the exporter's currency. More homogeneous products, such as crude oil and primary commodities, are typically invoiced in an international

\footnotetext{
${ }^{12}$ See Kenen (2009) for an overview of the topic. To my best knowledge, Cohen (1971: p.18) is the earliest of this 3 by 2 matrix. Kenen (1983: p.16) is widely cited. This framework has been used by several authors, including, for example, Chinn and Frankel (2005) and Gao and Yu (2009). However, both authors include "invoicing trade and financial transactions" under "medium of exchange." This does not match the usage of "invoicing" in the literature on "invoicing currency." Invoicing is the same as denomination so that it should be under "unit of account." Medium of exchange is the currency of actual payments and settlement.

${ }^{13}$ International Monetary Institute of Ren Min University produces an annual report of the RMB internationalization. The most recent issue is Ren Min University (2016).

${ }^{14}$ Ito, et al. (2012) explains why the Japanese exporters choose the US dollar (third currency) as an invoice currency of semi-finished goods exports to Asian. They are part of a global production and distribution chain that ends in the US retail markets. The Japanese exporters felt it would avoid an overall currency risk if all trades in the chain are invoiced in US dollars.
} 
currency such as the US dollar (McKinnon, 1979).

For financial transactions, the denomination of financial products - bonds, equities, and loans - that are traded internationally is a private-use unit of account. Interest in denominating financial products by foreign issues in the currency is one aspect of internationalization; another is domestic issuers' offshore issue being denominated in the domestic currency.

In order to measure the private-sector usage of the unit of account, the best statistics are the ratio of export and imports of the country in its own currency, and the ratio of exports and imports of other countries in their own currencies. For example, the higher ratio of Japanese yen-denominated exports and imports is evidence of increasing the role of the unit of account for the Japanese yen.

\subsection{Private-use Medium of Exchange}

Settlement currencies for trade and securities transactions are almost always the same as invoice and denomination currencies, respectively, although theoretically they can be different from each other. ${ }^{15}$ Hence, the reasons and explanations for the unit-of-account use also apply to the use in settlement. In many countries, the private practices are left to the private sector. So, the usage of the currency in the private sector reflects rational decisions of private sector participants. However, if policy is restricting the usage of the domestic currency in trade and financial products, policy to remove the restrictions may contribute to increasing usage of the currency. This was the case in China in 2009-10.

It is very difficult to obtain data on the uses as the medium of exchange. Two data sources are well-known: The Swift settlement data and the BIS triennial survey. The Swift, the global interbank payment system, publishes monthly the settlement data by currency. The ranking shows the actual usage through the Swift system. This includes settling both exports and imports as well as financial transactions. The BIS conducts every three years a survey of all exchange rate transactions covering all banks and other financial institutions in almost all countries. National central banks cooperate to obtain data from all types of banks and financial institutions. They record all exchange rate transactions for the month of April (every three years). After adjusting for double counts (as every transaction involves two banks, which individually report to the central bank), the BIS publishes a report of the exchange rate usage (by currency pairs and by country, among others).

15 The following example illustrates a case where the invoice and settlement currencies are different. Suppose that exports are contracted as 1 million RMB. But on the date of payment, the recipient can request that the money should be sent in the US dollar to the bank account in the New York, converted at the prevailing exchange rate on the day. 


\subsection{Private-sector Store of Value}

This is achieved by denominating deposits and securities in the currency and allowing foreign investors to trade them. Whether foreigners wish to hold assets in the currency is a test of trust and prospects of economic benefits. Emerging economies often find it difficult to denominate government bonds in their own currency and market them abroad, as foreign investors are wary of possible devaluations. However, a rapidly growing emerging country that is expected to experience appreciation of its currency, such as China, may face fewer obstacles. Foreign demand for RMB-denominated bonds in Mainland China (Panda bonds) and Hong Kong (Dim Sum bonds) have grown rapidly and may be expected to expand further. These are the store-of-value products as well as the evidence of unit-of-account.

\subsection{Official-use unit of account}

A unit of account in the official sector (of other countries) may take several forms. First, if another country pegs its currency to the country, then the currency has an element of international reserve currency. There are many countries that peg their currencies to the US dollar. Some central European countries peg their currencies to Euro, so the Euro is another international reserve currency. In Asia, Hong Kong is pegging its currency to the US dollar, and Brunei to the Singaporean dollar.

Second, when the currency is in the basket that is widely used, then the currency may be regarded as an international currency. The Monetary Authority of Singapore is explicit about their pursuit of the exchange rate stability to a basket value of their trading partners. Those currencies in the Singaporean basket, which are not officially disclosed, may be counted as a broadly-defined international reserve currency. In the post-AFC and postGFC world, many countries manage their currencies flexibly, without announcing the fixed, crawling, or basket currencies. Here, it may be more important to examine implicit weights of a de facto basket of a currency. If an exchange rate of the foreign currency is co-moving with the currency in question, it is an indication that the currency may be a part of basket of other currencies. For example, if a Malaysian ringgit co-moves with the Chinese yuan, more so than the US dollar and other currencies, then the Chinese yuan may be regarded as a part of the Malaysian ringgit basket anchor.

Third, a similar currency basket has been used in the IMF. Special Drawing Rights (SDR), created in 1969, were conceived as a unit of account at IMF. They were also meant to supplement the quota of shares by major member countries, by increasing liquidity from the IMF to member countries, which many think did not work as a tool for crisis 
prevention or management. The four currencies have been in the SDR basket since the creation of the Euro and eliminating some European currencies: the US dollar, the Euro, the Japanese yen, and the British pound. The IMF loan to a crisis country is denominated in SDR, but actual payments and re-payments are done in one of the SDR composition currencies. In that sense, the SDR is a unit of account, but not a settlement currency. When a new currency is added to the list of SDR composition currencies, it is an achievement to become an international currency in the official-sector unit of account. In 2009, Governor Zhou of the People's Bank of China argued that the Chinese RMB should become an SDR composition currency. ${ }^{16}$ Seven years later, in October 2016, this was realized.

Fourth, when a government or international agency, such as the World Bank, issues a long-term bonds that are denominated by the currency, it is another measure that the currency is an internationally-recognized unit of account for official financing. Many emerging market countries issue dollar-denominated international government bonds, most of them being issued in New York or in London. This is a piece of evidence that the US dollar is still the dominant international reserve currency.

\subsection{Official-use Medium of Exchange}

The most prominent official role as medium of exchange is when the currency is used by other monetary authorities in foreign exchange market interventions. Another function is to use the currency to lend currencies to other governments. For example, some Japanese ODA - official lending - has been denominated and often delivered in yen, contributing to the yen's status as an international currency. If other countries accept the currency as a bilateral loan, then it is an evidence of international settlement. Traditionally, international development assistance is a source of such official usage.

More recently, central banks engage in currency swaps. When short-term liquidity is needed a central bank can request a loan from another central bank with a promise of reverse transaction in the future date. If the other side (counterpart country) requests or accepts the currency of a country, then it is a good sign that the currency has an

16 Zhou (2009) advocated the reform of SDR as a part of international monetary system reform. Although he did not mention RMB by name, it was implied that China wished RMB to become an SDR currency: "The basket of currencies forming the basis for SDR valuation should be expanded to include currencies of all major economies, and the GDP may also be included as a weight." Since China was the third largest economy by GDP at the time of his writing (and would become the second largest in 2010), it was clear that Governor Zhou thought that RMB should be a SDR comprising currency. In this article, he proposed a much wider use of SDR as a supra-national currency to be used in private sector transactions as well as official transactions. 
international reserve currency status. A good example is the Federal Reserve extending swap lines to many advanced countries and some emerging market economies in 20082010. This was the swap between the US dollar and the currency of the counter-party central bank. The US dollar, as the international reserve currency, was demanded globally at the time of crisis.

Another case of the currency swap agreements was the Chiang Mai Initiative, in which some of the swap agreement was between currencies of participating countries, like Chinese Yuan and Japanese yen. However, it was not used. When it became CMI-M, the reserve pooling was done in the US dollar. The requesting country requests to receive US dollar to other countries with its local currency.

China has been very active in building bilateral local swap lines with other countries in promotion of the usage of RMB. This is quite a unique effort in the category of official sector settlements.

\subsection{Official Store of Value}

The official sectors holds assets for various reasons. One of them is foreign reserves. All countries build up and hold foreign reserves (international reserves). In many cases they are part of central bank balance sheets and in some other cases, including Japan and the United States, they are partly held in the government's fiscal account. The currency composition of foreign reserves reveal how a country regards the importance-liquidity and safety in preserving values - of other currencies. Hence, the extent to which other countries hold the currency is a measure of their internationalization. IMF has collected data on the currency composition of foreign reserves, and published this in the COFER statistics.

In addition to foreign reserves, some countries have built up sovereign wealth funds that have a more long-term horizon for investment. The assets of a country, denominated in the currency, is included in the portfolio of sovereign wealth funds of other countries, which is also a measure of their internationalization.

\subsection{Data to examine the Chinese case}

As the definition of the international reserve currency is systematically reviewed, hopeful data sources to numerically trace the internationalization are identified. They can be summarized as $<$ China $>$ entry in Table 2 that was discussed earlier.

In the next section, these data are analyzed to examine how the RMB internationalization has advanced in the recent years. 


\section{RMB internationalization}

\subsection{Trade invoicing and Settlement}

Trade settlements in RMB have been promoted by the People's Bank of China. Regulations on the use of RMB was lifted for trade between a few Chinese cities and Hong Kong in 2009. ${ }^{17}$ Deregulation was extended to 20 provinces, municipalities and autonomous regions, including Beijing, in June 2010. On August 23, 2011, another 11 provinces and autonomous regions were permitted to use RMB in cross-border trade settlements and with trading partners anywhere in the world. ${ }^{18}$ During the first six months of 2011, RMB-settled trade transactions increased to 957 billion yuan, a 13-fold increase over the same period in the previous year. ${ }^{19}$ During 2014-15, RMB settlements were in the rage of 1.5-2.0 trillion yuan per quarter. ${ }^{20}$

\subsection{Private Settlement: SWIFT}

The SWIFT (Society for Worldwide Interbank Financial Telecommunications) is a global payment system among the financial institutions in that messages of payment instructions can be securely transmitted through a standardized system of codes. Which currencies are used for payment is a good indicator of the international use of the currency. SWIFT (various issues, 2016) shows the rankings in usage of various international currencies.

The ranking of RMB in the SWIFT payments has risen quickly from number 20 (with a share of $0.25 \%$ ) in January 2012 to number 5 (with a share of 2.09\%) in June 2015. However, it has plateaued from 2015 to 2016, with a slight drop in the ranking and share. The RMB is ranked number 6 with a share of $1.72 \%$ in June 2016, as shown in Table 3. The global ranking of currencies are shown in Figure 4.

$$
<\text { Table } 4><\text { Figure } 4>
$$

The ranking is rather stable between 2014 and 2016. The USD and EUR are clearly number 1 and 2 currencies in global settlement. The two currencies account for more than $70 \%$ of the total settlement values. The British Pound is a distant third and the Japanese yen is fourth. They are followed by the Canadian dollar, Chinese yuan, Australian dollar

\footnotetext{
17 The "pilot program" announced in April 2009 had two types of coverage of region and trading partners. Firms in Shanghai, Shenzhen, Guangzhou, Zhuhai, and Dongguan were allowed to invoice and settle their trade in RMB with Hong Kong and Macau firms. Firms in Yunnan and Guangxi were allowed to trade with firms in ASEAN.

${ }^{18}$ See "News" on August 23, 2011 of the People's Bank of China:

http://www.pbc.gov.cn/publish/english/955/2011/20110830143601145186005/201108301436011451

86005_html

${ }^{19}$ Nikkei Veritas, September 18, 2011 (in Japanese).

${ }^{20}$ Reported in Mizuho, "Cross-border RMB settlements."

http://www.mizuhobank.com/service/global/cndb/rmb/pdf/cross_border.pdf
} 
and Swiss Franc, which are in a group with not so different shares.

\subsection{Private Settlement, BIS Triennial Survey}

Table 4 shows the time series change in the ranking and share of the currency transactions depicted by the BIS survey. ${ }^{21}$ Since they count the exchange rate (currency pair) transactions, each transaction is double counted in two currencies. Thus, the total is 200\%. The US dollar and Euro have been number 1 and 2, as they were in SWIFT. Japanese yen is a distant third, followed by the British Pound. The top four spots have not changed since 2001. The Australian dollar has risen to the number 5 spot, overtaking the Swiss franc in 2010. The Canadian dollar has been number 7. Then, the Mexican peso rose from number 14 in 2010 to number 8 in 2013; and the Chinese yuan rose from number 17 in 2010 to number 9 in 2013, and then to number 8 in 2016.

$<$ Table 4>

The position of the Chinese yuan, measured in SWIFT and BIS, in 2016 is around number 5 to 7. Jumping ahead to the discussion of SDR, it is ranked just behind the big four currencies, along with the Australian dollar.

\subsection{Deposits, Bonds and Equities}

When nonresidents would like to hold assets denominated in RMB (as a store of value), that should be possible for an internationalized currency. However, there exist many controls in this area. Most of the mainland (on-shore) assets - domestic bonds and equities - are not available to all foreigners. Instead RMB assets are offered in the offshore market in Hong Kong. RMB deposits have been offered since 2004. Chinese debt securities - typically RMB-denominated bonds - can be issued in Mainland China by foreigners (Panda bonds) or offshore (in other countries) for foreigners (Dim Sum bonds).

The RMB deposits in Hong Kong were allowed in February 2004, and they quickly became popular. The growth in deposits became sharply higher in 2010, increasing from 22 billion yuan in December 2009 to 315 billion yuan in December 2010. The outstanding balance of RMB deposits in Hong Kong reached 1 trillion yuan in December 2014. However, the outstanding balance started to fall. It fell to 732 billion by May 2016. The movement is shown in Figure 5.

$<$ Figure $5>$

The timing of the increase and decrease of RMB deposits seems to correlate with the RMB exchange rate vis-à-vis the US dollar (Figure 1). The following regression supports the casual observation that an increase in the RMB deposits (RMBDEPO) in Hong Kong

21 See BIS (2013, 2016). 
is driven by the change in the RMB vis-à-vis the US dollar (CNYUSD). In addition, as the number of authorized institution engaged in RMB businesses (NBank) increases, it is expected that RMB deposits will increase, as a new customer base in relation with a bank will be added to the potential customers. The following equation is regressed for the period of April 2004 to May 2016, where $\Delta$ indicates the rate of changes for RMBDEPO and CNYUSD, and the difference from the previous month for NBank. The explanatory variables are lagged one period to reflect the time for recruiting customers and customers' actions. The results are shown in Table 5.

$$
\Delta \text { RMBDEPO }_{t}=\mathrm{c}_{1}+\mathrm{c}_{2} \Delta \mathrm{CNYUSD}_{t-1}+c_{3} \Delta N \text { Bank }_{t-1}+\varepsilon_{t}
$$

Although it depends on the specification and sample period, the yuan appreciation of 1 percent causes an increase in RMB deposits by 3 - 4.5 percent in the following months. The increase in the number of authorized banks to engage in RMB business contributed to the large increase in RMB deposits in 2010-11; the effect becomes small as the number has become almost constant (at around 145) by 2016.

\section{$<$ Table 5>}

The first RMB denominated offshore bonds (Dim Sum bonds) were issued in July 2007 by the China Development Bank. The issuance of Dim Sum bonds in Hong Kong sharply increased from 2010 to 2011, as restrictions on types of issues were deregulated for banks only to other corporations. Later, Dim Sum bonds could be allowed and encouraged to issue Dim Sum bonds. The outstanding bonds amounted to 367 billion yuan in October 2015, with $18 \%$ by the Ministry of Finance of China; $19 \%$ by Hong Kong banks and enterprises; $22 \%$ by Mainland banks and enterprises; and $41 \%$ by entities outside Mainland China or Hong Kong. ${ }^{22}$ However, the issuance of Dim Sum bonds in Hong Kong slumped in 2015 as the RMB started to depreciate vis-à-vis the US dollar. Foreigners' interest in Dim Sum bonds seemed to be similar to that in RMB bank deposits. They hope to benefit from currency appreciation. Another factor that adversely affected bond issuance in 2014 was the equity boom in Shanghai, where Chinese companies could easily raise their capital cheaply rather than in the debt market. Since 2014, Dim Sum bonds have been issued in several cities globally. The United Kingdom issued a 3 billion Dim Sum bond in October 2014, shortly after the China Construction Bank was designated as an RMB clearing bank in London. In April 2016, Hungary became the first central European country to issue a Dim Sum bond, following the Bank of China opened a RMB clearing center in Budapest in October 2015.

Onshore RMB denominated bonds (Panda bonds) have been issued since October 2005. The first issues were by the International Finance Corporation and the Asian

22 Hong Kong Monetary Authority (2016, p. 10). 
Development Bank. In the beginning, issuers were limited to international financial institutions. Like the Dim Sum bonds, regulation on the issuers of the Panda bonds, as well as regulation on remittance of proceeds, were relaxed in 2010. At the end of February 2016, a total of 20.5 billion yuan was raised in Panda bonds with 15 offerings. Issuers include the Republic of Korea; the Province of British Columbia, Canada; Daimler; and banks based in Hong Kong. In August 2016, the Polish government became the first European country to issue panda bonds ( 3 billion yuan).

There are three types of Chinese equities - $\mathrm{A}, \mathrm{B}$, and $\mathrm{H}-$ and three representative stock exchanges: Shanghai, Shenzhen, and Hong Kong. A-shares are the RMBdenominated domestic equities of Mainland Chinese companies that traditionally only domestic residents can trade. A-shares are traded both in Shanghai and Shenzhen. Since 2003, select foreign institutions, registered in the Qualified Foreign Institutional Investor (QFII) system, were allowed to participate in the A-share markets. The foreign investors can bring in funds up to the specified amounts, and restrictions apply as to how much they can take out.

B-shares are denominated in US dollars in Shanghai and in Hong Kong dollars in Shenzhen, effectively only for foreign investors due to restrictions on residents on foreign exchange transactions.

H-shares are traded in the Hong Kong Stock Exchange in the HK dollar. Many companies' shares are traded both in A-shares and B-shares, as well as A-shares and Hshares. Due to capital controls, prices may not be exactly the same all the time. There used to be arbitrage opportunities if someone could trade in the two markets at the same time.

Between Hong Kong and Shanghai, reciprocal access, called the Shanghai-Hong Kong Connect, was established in November 17, 2014. Under the arrangement, investors in each market can trade shares on the other market (A-shares in Shanghai and H-shares in Hong Kong) using their local brokers and clearing houses. This is supposed to significantly lower the barriers for foreigners to invest in Mainland China.

There is an index measuring how much the A shares deviated from the $\mathrm{H}$ shares of the corresponding companies. Because of the remaining capital controls, the stock prices of the same company in the two markets can deviate even with the Shanghai-Hong Kong Connect. Without full liberalization on short-selling, a riskless arbitrage would be difficult.

The AH Premium index (HSAHP) is calculated as a part of the Hang Seng Indices series and made available by the company. The HSAHP tracks the average price premium, or discount of A shares over $\mathrm{H}$ shares, for the largest and most liquid Chinese companies 
that are traded in both the A-share markets and H-share markets. ${ }^{23}$ When HSAHP is less (more) than 100, A shares are trading at a discount (premium, respectively) compared to $\mathrm{H}$ shares. The 100 level shows that $\mathrm{A}$ shares are at a par with $\mathrm{H}$ shares on average. This index, which deviates from the 100 mark, is widely regarded as the evidence for existing capital controls on cross-border equity investment.

Two questions are investigated in connection with the HSAHP. First, since the Shanghai-Hong Kong Connect is supposed to have made the cross-border arbitrage possible, it is an important question whether the deviation from the par becomes noticeably smaller after the introduction of the Shanghai-Hong Kong Connect, implemented on November 17, 2014. Second, as HSAHP implies a capital inflow or outflow pressure, which represents blocked capital controls, it should be correlated with another indicator of capital flow pressure.

Currently, the RMB has two markets: the offshore market in Hong Kong $(\mathrm{CNH})$ and the onshore Shanghai (CNY) market. If $\mathrm{CNY}$ is more appreciated than $\mathrm{CNH}$, i.e., $(1 / \mathrm{USDCNY})>(1 / \mathrm{USDCNH})$, then there is capital outflow pressure that is blocked by capital controls, and vice versa, where USDCNY (USDCNH) is the exchange rate quoted in the market, i.e., the value of the USD in terms of CNY (CNH, respectively). We define the YH Premium as the ratio between USDCNY and USDCNH:

$$
\text { YH Premium }=100 * \frac{\left\{\frac{1}{\mathrm{USDCNY}}\right\}}{\left\{\frac{1}{U S D C N H}\right\}}=100 \frac{C N H}{C N Y}
$$

Similarly to AH Premium, the YH Premium shows that CNY is traded at a premium (discount) to $\mathrm{CNH}$ if the $\mathrm{YH}$ Premium is higher (lower, respectively) than 100. It is theoretically and practically expected that the $\mathrm{AH}$ Premium and $\mathrm{YH}$ Premium are correlated (or co-moving), since capital flow pressure in the capital markets and that in the foreign exchange market are expected to be correlated.

Figure 6 shows the movements of AH Premium and YH Premium. We examine the behavior of AH Premium, with a special focus on the regulatory change of ShanghaiHong Kong Connect; and compare the movements of AH Premium and YH Premium.

\section{$<$ Figure 6 $>$}

First, the vertical line shows the November 17, 2014 starting day of the Shanghai-Hong Kong Connect. Two observations in answering the two questions posed above emerge from the figure. First, the Shanghai-Hong Kong Connect does not seem to lower the capital controls effectively between the Hong Kong H share market and the A shares. In

\footnotetext{
${ }^{23}$ It is calculated by the Hang Sen Index, www.hsi.com.hk. See for example, the August issue on the AH Premium index: http://www.hsi.com.hk/HSI-Net/static/revamp/contents/en/dl_centre/factsheets/FS_AHPe.pdf.
} 
fact, a significant deviation continued to exist after the day of the regulatory change.

Second, the AH Premium and YH Premium move together. Although there are some periods when the two indicators deviate, they co-move most of the time.

$$
\operatorname{AHPremium}(\mathrm{t})=1.124 \text { YHPremium }(\mathrm{t})+\mathrm{e}(\mathrm{t})
$$

$$
(0.004) * * *
$$

Where () shows the Standard error. The coefficient is statistically significant at $1 \%$.

In summary, for foreigners, there are three ways to invest in the Chinese equities markets. First, QFII (Qualified Foreign Institutional Investors) are transactions in USD or other foreign currencies, which is invested in Mainland China. This has been traded since December 2002. Second, since December 2011, another channel has opened up. Foreign investors can obtain RMB in offshore markets (typically, Hong Kong), and invest in onshore markets. RQFII (Renminbi Qualified Foreign Institutional Investor) made it easier for foreigners who already have access to the offshore RMB markets; transactions are conducted in RMB. Third, The Hong Kong Shanghai Connect started on November 2014, enabling foreigners to purchase A-shares in Hong Kong. Table 6 summarizes these three channels.

$<$ Table 6>

\subsection{Official Unit of Account: High weights in baskets of other currencies}

No country is pegging its currency to the RMB. However, some Asian currencies seem to move closely with China. For a trading partner of China, it is for their benefit to pursue the stability of the currency vis-à-vis the Chinese yuan. As the size of China becomes large, so are their imports and exports. It is indeed natural that some countries that rely on Chinese markets as export destinations manage their currencies to follow the Chinese yuan.

The usual method of examining the co-movement is a Frankel-Wei regression, which regresses a currency on other currencies to find out weights. The difficulty in answering this question is the co-movement (multicollinearity in a regression) between the RMB and USD. ${ }^{24}$ It was indeed a problem in earlier studies. ${ }^{25}$ Fortunately, in recent years, the Chinese authorities increased flexibility against the US dollar, so that a test of separating

\footnotetext{
${ }^{24}$ Ito (2010b; Tables 4 and 5) ran the Frankel-Wei form of regression for the period of July 4, 2005 to December 31, 2008. Weights of the USD was found to be 96\%; Euro 3\%; and Yen 1\%. Similar regressions were put to test in Chen, Peng, and Shu (2009). See also Ito (2008).

${ }^{25}$ According to Ito (2010b, Table 5), when an Asian currency is regarded as a basket currency, the weight of RMB, after controlling for US dollar, Japanese yen, and the Euro, is as high as $49 \%$ for Singapore; the weights for Indonesia and Malaysia are in the range of $40 \%-46 \%$; and the weights for Thailand, Taiwan, and India are in the range of 30\%-39\%. Korea, 0.28 and the Philippines 0.14 were statistically not significant.
} 
the RMB and USD became possible with a higher statistical confidence.

First, a standard Frankel-Wei regression is attempted. The specification is as follows. The numeraire is the Swiss Franc. An Asian currency is regressed on the US dollar (USD), Euro (EUR), the Chinese Yuan (CNY) and the Japanese yen (JPY). The Swiss franc $(\mathrm{CHF})$ is chosen as the numeraire currency, namely those currencies of interest as expressed in a ratio to the Swiss franc. The coefficients are restricted to be summed to 1 . The equation is as follows:

$$
\Delta\left(\frac{\mathrm{ASIA}}{C H F}\right)_{t}=\beta_{1} \Delta\left(\frac{U S D}{C H F}\right)_{t}+\beta_{2} \Delta\left(\frac{E U R}{C H F}\right)_{t}+\beta_{3} \Delta\left(\frac{C N Y}{C H F}\right)_{t}+\left(1-\beta_{1}-\beta_{2}-\beta_{3}\right) \Delta\left(\frac{J P Y}{C H F}\right)_{t}+\varepsilon_{t}^{A s i a}
$$

Since we would like to differentiate the effects of USD and CNY on an Asian currency, the regression works for the period when the CNY is fixed to USD. Recall that the RMB has four distinct regimes in the last 15 years, as shown in Figure 1.
I. Jan $2001-$ June 2005
Fixed
II. July 2005 - June 2008
Crawling Peg
III. July 2008 - June 2010
Fixed (during GFC)
IV. July 2010 - May 2016
Managed Float

So, first, we do not use periods I and III in our sample of the Frankel-Wei regression, since the USD/CHF and the RMB/CHF would have a correlation coefficient near unity during those periods. So, we use samples in Period II and IV. We fine-tune sample periods on a daily basis:

Sample periods

$\begin{array}{lll}\text { (II) July 20, 2005 - July 18, 2008 } & \text { (crawling peg) } \\ \text { (IV) June 16, 2010 - June 24, 2016 } & \text { (flexible crawling peg) }\end{array}$

The (IV) period can be divided into an appreciation phase and a gradual and accelerating depreciation phase. The highest rate, with the benefit of hindsight, for the Chinese yuan vis-à-vis the US dollar was recorded on January 14, 2014 at 6.0412 Yuan per USD. So, this regression in addition to the following sub-periods are examined.

(IV a) June 16, 2010 - January 14, 2014

(IV b) January 15, 2010 - June 24, 2016

Coefficients of the US dollar (USD), Euro (EUR) and the Chinese RMB (CNY) are estimated and reported in Tables 8 and 9 for periods of (II) (IV) (IV a) and (IV b). Table 7 generally indicates that the Asian countries (Indonesia, Korea, Malaysia, Philippines, Singapore and Thailand), the US dollar had a higher weight than the Chinese yuan in Period II (CNY following a crawling peg). The magnitude of US weight was higher in Indonesia and the Philippines (exceeding 0.7), and lower in Singapore. In Period (IV), the 
weight of the Chinese yuan increased from Period (II), for almost all countries. In Singapore and Thailand, the CNY weight changed very little. In Period (IV), the CNY weight was quite high (higher than 0.7) in Indonesia, Korea, and Malaysia. Except in Thailand, the CNY weight became higher than the USD weight after the global financial crisis. In this sense, the Chinese yuan, rather than the US dollar, became a currency to follow for Asian currencies.

$<$ Table $7>$

In Table 8, currency behaviors are examined for the sub-periods of period (IV). Malaysia ringgit (MYR) consistently follows the Chinese yuan: the coefficient is very close to 1 , suggesting that MYR is effectively pegged to CNY in the two sub-periods. Indonesia and Korea also show the high weights on the Chinese yuan. For these three countries, the weight on the USD is very close to zero, as it is statistically not significant (or the null of being 0 is not rejected). For the Philippines and Thailand, the dollar weight was higher than the Chinese yuan in the sub-period (IV b). The Singapore, the dollar, euro, and Chinese yuan were almost equally important in sub-period (IV a), but the weight of the Chinese yuan increased in the sub-period (IV b).

\section{$<$ Table $8>$}

This conventional Frankel-Wei regression has been very popular, but two concerns have been pointed out: a choice of numeraire currency, and possible multicollinearity among explanatory variables. In general, a choice of the numeraire currency matters. If the numeraire currency moves widely, that may drive the results. If the numeraire currency has a high correlation with the currency of interest, the explanatory variable loses its significance. The collinearity is of particular concern when a currency that comoves with another explanatory variable is added to the equation.

Kawai and Pontines, (2016) pointed out that the Swiss monetary authority introduced the ceiling of 1.2 Swiss franc to the euro from September 9, 2011 to December 18, 2014. The rate was at or near the ceiling for a long time, which means the EUR/CHF rate stayed almost a constant. Hence, the Frankel-Wei regressions, especially the EUR coefficients, became unreliable. Kawai and Pontines (2016) proposed to have the New Zealand Dollar (NZD) as a base (numeraire). Second, since the CHY/USD was heavily managed by the Chinese authority, it was difficult to separate the influence from CHY and the influence from USD. It was a policy, and so announced, that the daily movement was limited, as the benchmark rating was determined by the authority. The actual movement was much less than the policy limit of daily change. Therefore, the daily movement of CHY/USD was very small. In a sense, it is suspected that CHY and USD have multicollinearity. We do not use samples from the Chinese fixed exchange rate regimes, namely Periods I and 
III. Second, the flexibility of CHY/USD has increased lately. Period II was a typical crawling peg, a series of very small appreciations of the CHY/USD every day. However, Period IV contains the regime of an appreciation trend and a depreciation trend, and daily movements were much more flexible. Period IV, under a casual observation, may escape the problem of multicollinearity. We will examine shortly with the Variance Inflation Factor, a diagnostic test for multicollinearity.

Below, we adopt the Kawai-Pontines proposal of using NZD as a numeraire, but did not follow their procedure to address the possible multicollinearity. First, a regression is modified with NZD as a numeraire

$$
\Delta\left(\frac{A S I A}{N Z D}\right)_{t}=\beta_{1} \Delta\left(\frac{U S D}{N Z D}\right)_{t}+\beta_{2} \Delta\left(\frac{E U R}{N Z D}\right)_{t}+\beta_{3} \Delta\left(\frac{C N Y}{N Z D}\right)_{t}+\left(1-\beta_{1}-\beta_{2}-\beta_{3}\right) \Delta\left(\frac{J P Y}{N Z D}\right)_{t}+\varepsilon_{t}^{A s i a}
$$

The results are shown in Tables 9 and 10, comparing Periods II and IV, and in Table 11, comparing Periods (IV a) and (IV b). The estimated weights of CHY for the Asian currencies with the NZD as numeraire are much higher than those with the CHF as a numeraire. The CNY weights for all Asian currencies are estimated to be higher than 0.7 in both Periods II and IV. The estimated coefficients for the USD for all Asian currencies are less than 1 in both periods (except Malaysia in Period IV). The estimated CNY weights are higher than previous estimates, especially for Period II. The results imply that as soon as the China introduced the reform in July 21, 2005, Asian currencies started to follow the Chinese yuan rather than the US dollar, although Asian currencies were much more flexible than the Chinese yuan.

\section{$<$ Tables 9 and $10>$}

Next, we check whether our results suffer from multicollinearity. A common diagnostic test is the Variance Inflation Factor (VIF). This rule of thumb states that if the number exceeds 5, a multicollinearity should be suspected; and if the number exceeds 10 , a serious multicollinearity may exist. Table 11 shows the VIF for explanatory variables used in Tables $8-11$. The regressions with CHF as a numeraire suffers from multicollinearity, but the degree of the problem declined from Period II to Period (IV a) to Period (IV b). For regressions with NZD as a numeraire, multicollinearity was not a concern for Period IV or its sub-periods of Period (IV a) and (IV b).

$<$ Table $11>$

In order to supplement the Frankel-Wei type regression, which may be sensitive to the choice of numeraire and multicollinearity, we employ a more direct analysis known as an event analysis. Do Asian currencies tend to appreciate (depreciate) vis-à-vis the US dollar when the Chinese yuan appreciates (depreciates, respectively), by a large amount (a jump), vis-à-vis the US dollar? A jump in the Chinese yuan should reflect an important 
policy change, such as on July 21, 2005 (an appreciation jump and the start of crawling peg) and August 11, 2015 (a depreciation jump and the start of a more "market determined" movement). Whether the Asian currencies move by a large amount with the Chinese yuan, when the Chinese yuan moves vis-à-vis the US dollar on the Chinese "news" (rather than US news or an Asian currency news), that would be a good indication that Asian currencies co-move with the Chinese yuan. The following regression was employed:

$$
\Delta\left(\frac{A S I A}{U S D}\right)_{t}=\beta_{1} \Delta\left(\frac{U S D}{C N Y}\right)_{t}+\varepsilon_{t}^{A s i a}
$$

Day $t$ is limited to days of jumps. For the explanatory variables, two types of "jumps" are chosen: the largest 30 jumps (in absolute terms) since the fixed exchange rate regime was abandoned (July 21, 2005); and large changes defined by the threshold of changes more than $0.1 \%$ (in absolute terms). According to the latter criterion, 694 samples were chosen and this is about $30 \%$ of the total days of Periods II and IV.

Table 12 shows the following results. For the currencies of Cambodia, Lao, and Vietnam, they do not respond to the Chinese yuan jumps at all. They are on their own regime (closer to the US peg), irrespective of the CNY movement. For the currencies we examined in Tables 8 to 11 , the $\beta_{1}$ coefficients are all significant, except for the Korean won for the 30-largest-jump samples. The magnitude of coefficients vary. Malaysia ringgit moves $92 \%$ of the magnitude of CNY jumps (of $0.1 \%$ threshold) and $70 \%$ of the magnitude of the CNY 30 largest jumps. Similarly, Indonesian and Singaporean currencies tend to jump by $60-70 \%$ of the magnitude of the CNY jumps (in either threshold definition). The Philippine peso moves $30-40 \%$ of the magnitude of the CNY jumps; the Thai Bart moves 54\% of the magnitude of CNY 30 largest jumps and 44\% of the $0.1 \%$ or more jumps. The Korean won followed the CNY move, by $70 \%$ of the magnitude of the jumps in cases of more than $0.1 \%$ changes, but the response to the 30 largest jumps are statistically insignificant.

\section{$<$ Table 12>}

In sum, Asian currencies have put more weight on CNY than USD in their implicit basket weights after the global financial crisis. As the Chinese yuan has increased its flexibility vis-à-vis the US dollar, Asian currencies are more likely to co-move with the Chinese currency than the US dollar. When the Chinese yuan appreciates vis-à-vis the US dollar, the Asian currencies tend to appreciate vis-à-vis the US dollar; and when the Chinese yuan depreciates vis-à-vis the US dollar, the Asian currencies tend to depreciate vis-à-vis the US dollar.

\subsection{Official Medium of Exchange}


The RMB is starting to be used in these various types of payments. It has been used in border trade with cash settlements in the Lao Republic, Vietnam, and Myanmar. Gao and $\mathrm{Yu}(2009)$ also report that, in Mongolia, " $60 \%$ of the cash in local circulation is in renminbi"; that the RMB is also accepted in Hong Kong and Taiwan; and that "Cambodia and Nepal announced that the official circulation of the renminbi in their markets is welcome." However, we do not have any quantitative measures for this.

Although China is still a large borrower of development loans from the World Bank and Asian Development Bank, China has increased its own Official Development Assistance (ODA) to other developing countries, most notably to African countries. China does not belong to a group of donor countries at OECD DAC. It is difficult to examine data of Chinese ODA, in particular whether the assistance is denominated in USD or CNY, which is a question of interest here. The size of Chinese ODA is quite substantial. In one estimate (Kitano and Harada (2014)), the magnitude of Chinese ODA is close to that of France and quickly approaching the level of top 5 donors in OECD DAC. It is difficult to obtain information on whether Chinese ODA are denominated in US dollars, Chinese Yuan, or some other currencies. According to one data source, most of the loans are denominated in US dollar, but some are already in Chinese Yuan. ${ }^{26}$

Another official use as a medium of exchange is central bank swaps. When the central bank extends a swap line to another central bank, and implements it, the currencies were exchanged between the two central banks. This is an official use of currencies internationally.

There are two kinds of swap arrangements: one in normal times, when needs are anticipated, and another in crisis times when ad hoc arrangements are quickly forged. China has participated in the first type. First, China is an important country in the framework of the Chiang Mai Initiative (CMI) among the ASEAN+3 countries. In the CMI (before it was multilateralized), China extended six bilateral swaps, of which three (with Thailand, Indonesia, and Malaysia) involved China providing US dollars in exchange for the currency of another country; one (with the Philippines) involved China providing the RMB in exchange for the Philippine peso; and two (with Japan and South Korea) involved China providing RMB in exchange for Japanese yen and Korean won. ${ }^{27}$ The swap arrangement was two-way for Japan and Korea, but one-way for others (only from China to an ASEAN country). In a sense, RMB was accepted only by Japan, Korea,

\footnotetext{
${ }^{26}$ AidData by Open Data for International Development. http://aiddata.org/donor-datasets.

${ }^{27}$ For the size of the swap and other features, see Gao and Yu (2009; Table 3) and the home page of the Ministry of Finance, Japan:

http://www.mof.go.jp/english/international_policy/financial_cooperation_in_asia/regional_financial_ cooperation/index.htm\#CMI
} 
and the Philippines.

The best example of a swap arrangement during a crisis is the swap extended by the U.S. Federal Reserve Bank of New York to G10 countries, other advanced countries, and four emerging countries-South Korea, Mexico, Singapore, and Brazil. ${ }^{28}$ Between December 12, 2007 and February 1, 2010, the Federal Reserve committed credit lines to 14 central banks, including unlimited credit lines to the European Central Bank, Swiss National Bank, Bank of England, and Bank of Japan. Meanwhile, the European Central Bank provided euro swaps to four countries (Denmark, Hungary, Iceland, and Poland).

The People's Bank of China $(\mathrm{PBoC})$, for its part, provided crisis swap lines to Argentina (70 billion yuan), Belarus (20 billion yuan), Hong Kong (200 billion yuan), Indonesia (100 billion yuan), Korea (180 billion yuan), and Malaysia (80 billion yuan) in 2009. ${ }^{29}$ Even after the crisis abated, the PBoC continued to extend new commitments: in June 2010 to Iceland (3.5 billion yuan), and in June 2011 to Kazakhstan (7 billion yuan). Even after the GFC was over, China strongly suggested to have a swap agreement when a bilateral relationship reaches a certain milestone, such as the Premier's visit to the country. It is hard to imagine that Australia, UK, or ECB request from their side for a currency swap, so most of the arrangements are pushed from China. By the end of 2015, the People's Bank of China currency swap (excluding CMI-related) arrangements were made with 33 countries and regions, with a total amount of 3.31 trillion yuan. Figure 7 shows the growth of currency swaps from 2008 to 2015. Some of the growth in the amount is due to a repeat of the same countries with expanded amounts.

$<$ Figure $7>$

What is the purpose of these swaps? Since none of these countries, or financial institutions within them, had significant RMB liabilities, receiving RMB could not relieve a liquidity problem. But by extending these swaps, the PBoC could boast that it was doing its part to help countries in crisis. Moreover, the swaps promoted trade even if they were irrelevant as liquidity support. The announcement of the swaps was accompanied by a statement explaining that the arrangement was "for the purpose of promoting bilateral trade and investment and strengthening financial cooperation." China's goal was to encourage targeted countries to buy Chinese exports with RMB credit.

When the RMB is fully internationalized, the Chinese implementing currency swaps will amount to provide a safety net that may rival the International Monetary Fund. Even when a country cannot borrow in the international market, or from the IMF, China can

\footnotetext{
${ }^{28}$ See Goldberg, Kennedy and Miu (2011, Table 2) for details of arrangement chronology and actual terms of lending on the arrangements.

29 These countries and amounts are taken from Aizenman, Jinjarak, and Park (2011).
} 
help. ${ }^{30}$ The magnitude of assistance that may be limited by the agreement and possible moral hazard will be an issue.

\subsection{Foreign Reserves}

In the official sector, a currency can act as a store of value if it is held in the foreign reserves of other countries. Foreign reserves by currency composition are not usually disclosed by the monetary authorities, except for transparent ones in advanced countries, such as the US and Japan. The IMF's COFER database collects the currency decomposition from voluntary reports of IMF members, with a promise that only aggregate information will be disclosed to the public. However, even that promise is not good enough for some central banks. They have sizable foreign reserves of unnamed monetary authorities not reporting currency decomposition, so those reserves are "unallocated" for currencies, although they report the total amount of foreign reserves.

At the end of 2015, the total reserves of all countries amounted to the equivalent of 10.9 trillion US dollars in various currencies, of which 6.8 trillion dollars $(62 \%)$ are allocated to various currencies, while 4.1 trillion dollars $(38 \%)$ were not allocated. ${ }^{31}$ Among the allocated, 4.4 trillion dollars (64\%) were held in US dollars and 1.3 trillion dollars (19.8\%) were in Euro, followed by the British pound (4.9\%), the Japanese yen (4.0\%), Australian dollar (1.89\%), Canadian dollar (1.86\%), and Swiss franc $(0.28 \%)$. Since Chinese RMB is not reported in the COFER statistics, the share of RMB among allocated foreign reserves must be less than $0.28 \%$.

Figure 8 shows the time-series of the ratios in US dollar, Euro (German mark before 1999), British pound and Japanese yen among allocated reserves. The ratio of the euro slightly increased from 1999 to 2009, but has declined in the 2010s. The US dollar has been mostly between 60 and 70 percent in the last 20 years. The Japanese yen slightly declined over time.

\section{$<$ Figure $8>$}

The fact that the RMB does not show up in the explicit ranking of currencies held in the

\footnotetext{
${ }^{30}$ This may have already happened in Argentina: "In addition to using the swaps to facilitate trade in renminbi, China is also using the swap lines to provide loans to Argentina in order to bolster the country's foreign exchange reserves. In October 2014, a source at the Central Bank of Argentina reportedly told Telam, the Argentine national news agency, that the renminbi Argentina receives through the swap could be exchanged into other currencies. Argentina has had difficulty borrowing dollars on international markets since it defaulted on its debt in July and has faced shortages on a range of imported goods as a result. Swapping renminbi into dollars would enable companies to import more than they would be able to otherwise." Council on Foreign Relations (2016).

31 The ratio of unallocated reserves (currency decomposition not being reported) increased from $21.57 \%$ in 2000 to $47.50 \%$ in 2014 . The rapid growth of non-reporting foreign reserves can be only explained if the Chinese authorities are not reporting its currency composition.
} 
global foreign reserves is not favorable to the Chinese authorities' effort to make the RMB internationalized. China seems to be pushing to change this. From time to time, news appears that some central banks have agreed to hold RMB as foreign reserves. ${ }^{32}$

\section{SDR Composition Currency}

The Chinese authorities, expressed by Zhou (2009), made it clear that China would like to see reforms in the role of Special Drawing Rights (SDR), which is the unit of account in the IMF, and that the RMB should become an SDR composition currency. An important part of the motivations was the Chinese recognition that the GFC was a failure caused and/or propagated by the US dollar being an international reserve currency, Zhou (2009) citing the Triffin Dilemma. ${ }^{33}$ Instead, Zhou argued for an expanded role of the SDR: "A super-sovereign reserve currency not only eliminates the inherent risks of creditbased sovereign currency, but also makes it possible to manage global liquidity." As a super-sovereign currency, "the role of the SDR has not been put into full play due to limitations on its allocation and the scope of its uses." Zhou goes on to propose SDR become settlement and currency: "Set up a settlement system between the SDR and other currencies. ... The SDR ... could become a widely accepted means of payment in international trade and financial transactions. Actively promote the use of the SDR in international trade, commodities pricing, investment and corporate book-keeping."

Last and most importantly, Zhou (2009) suggests that the RMB be included among the SDR composition currencies: "The basket of currencies forming the basis for SDR valuation should be expanded to include currencies of all major economies, and the GDP may also be included as a weight." At the time of this writing, China, no. 3 in GDP in the world, was projected to overtake Japan in a year or two.

It is a majority view that the enthusiasm toward SDR as a reserve currency had been lost for decades among policy makers and economic scholars. The Triffin Dilemma became a moot question when the United States abandoned an obligation to convert the dollar to gold in 1971.

\footnotetext{
32 On June 25, 2016, China Daily reported that a leading Chinese investment bank said in a report that "The Monetary Authority of Singapore (MAS) announced on June 22 that it will include renminbi investments as part of its official foreign reserves from June." It was reported in China Daily (web version) on September 06, 2011 that Nigeria agreed to hold RMB as part of its foreign reserves after an agreement with the People's Bank of China: "Nigeria plans to invest 5 percent to 10 percent of its foreign exchange reserves in China's currency, the renminbi (RMB) or yuan, the country's central bank governor Lamido Sanusi said on Tuesday."

33 "On the one hand, the monetary authorities cannot simply focus on domestic goals without carrying out their international responsibilities; on the other hand, they cannot pursue different domestic and international objectives at the same time.... The Triffin Dilemma ... still exists." Zhou (2009).
} 
When Zhou (2009) was published, reactions outside China were perplexed: Why does China want its currency be an SDR composition currency, which may only carry prestige value? Isn't it far-fetched to desire SDR status when the currency does not have full convertibility?

Following the Zhou paper, China pushed the agenda of internationalization of the RMB. Getting into a status of SDR composition currency became both a means and an end. The RMB becoming a SDR composition currency is an important component to fill the void in the official role of the unit of account in the international currency matrix (Table 3), a means for the RMB to be recognized as an international reserve currency. However, the RMB internationalization was an agreeable objective to rally for liberalizing financial regulation and lifting capital controls. Many policy measures were taken to help RMB become an international currency: Adding flexibility to the Chinese yuan exchange rate, cautiously opening the capital markets to foreign institutions, and promoting the use of RMB for trade invoicing and settlement. All combined, they were a drive for wider usage of the RMB in each cell of the international currency matrix (Table 3). ${ }^{34}$

Six years after the Zhou (2009) speech, the IMF examined whether RMB should be included in the SDR as part of the quinquennial review. The staff recommended an inclusion of RMB as an SDR composition currency (IMF (2015a)), and so officially decided by the Executive Board (IMF (2015b)). In addition, the Board decided on the new shares among the newly formed basket of five currencies. The RMB was allocated a share of $10.9 \%$, surpassing the Japanese yen of $8.3 \%$ and the British pound of $8.1 \%$. The change from the previous standard to the current is shown in Table 13. The gain of $10.9 \%$ by the RMB in 2015 was made possible by a drop in Euro by 6.5 points, the GBP by 3 points, and the Japanese yen by 1 point.

\section{$<$ Table 13>}

The inclusion of the RMB is the first fundamental change since the German Mark and the French Franc were consolidated in the Euro. The Japanese yen had a share of $18 \%$ in 1995, but its share became less than half of its peak 20 years later.

Criteria for inclusion into the SDR composition currencies were two-fold: (a) those countries with the largest exports and (b) freely usable currencies. Selection criterion (a) ensures the currency of a large country in terms of the value of exports; it is important that a country can provide sufficient reserve assets. Selection criterion (b) ensures that the

\footnotetext{
34 Academic discussion on this topic is not deep, with the exception of Bénassy-Quéré and Capelle (2012), where the importance of the flexibility of RMB vis-à-vis is emphasized in order to make the inclusion to be relevant as a basket currency..
} 
currency is the most representative for use in the global trading and financial systems (IMF (2011)).

China has been the number 3 exporter after the Euro area and United States with the global share of $10.5 \%$ for the $2010-14$. It easily clears condition (a). In fact, if this was the sole criterion, Chinese RMB would have been adopted as an SDR currency in $2010 .{ }^{35}$

The definition of "freely usable currency" is a tricky concept. Many observers thought it would mean a fully convertible currency, that is, a currency without capital controls; and thus the RMB would not qualify. However, the IMF was explicit that full convertibility is neither necessary nor sufficient to be widely used. Rather, the IMF states that "A freely usable currency means a member's currency that the Fund determines (i) is, in fact, widely used to make payments for international transactions, and (ii) is widely traded in the principal exchange markets." (IMF, Articles of Agreement, Article XXX(f))

Hence, whether the currency satisfies condition (b) is almost equivalent to the question of whether the currency is internationalized based on the 6-cell currency internationalization matrix. It may run into a tautology: The currency of a large exporter is included in SDR if the currency is internationalized, while the currency is definitely internationalized if the currency is an SDR composition currency. Now all the efforts China made to have the RMB used in trade invoicing, settlement, and capital flows for foreigners can be regarded as coordinated efforts toward making the RMB freely usable.

IMF (2015a) gives the process of thinking about determining the "freely usable" concept or indicating "widely used" in global trade and financial transactions. Mainly, the IMF examined the three aspects of the "widely used" term: (i) How much RMB is held in foreign reserves of other countries; (ii) How much RMB is used in foreign exchange transactions; and (iii) how much RMB is used in international banking liability and international bond outstanding.

The criteria for foreign reserves can be examined in the cell, "Official Store of Value" above. As examined in sub-section 8.6, RMB in the "allocated" reserves in COFER must be very, very small, and not worth mentioning. This is the weakest aspect (cell) of the RMB in its pursuit of the SDR composition currency status. The IMF decided to conduct a special survey-separate from COFER - to obtain more data, presumably from previously "unallocated" reserve countries. The special surveys of 2013 and 2014 are compared with the COFER results in Table 14.

$<$ Table 14>

35 After the UK, the following countries are the large exporters: Korea (3.2\%), Singapore (2.7\%), Canada (2.7\%), Russia (2.7\%) and Switzerland (2.7\%), according to $\operatorname{IMF}(2015 a ;$ p. 8). 
No substantial difference between the COFER and special survey for USD and EUR. The Japanese yen share is slightly smaller in the special survey and the British pound share is slightly larger in the special survey. The shares of both the Australian dollar and Canadian dollar are slightly higher.

The largest difference between the two statistics is the share of RMB. However, the $\mathrm{RMB}$ is not in the COFER ranking, suggesting that its share is smaller than that of the Swiss franc, $0.27 \%$. However, the RMB share in the special survey claims $0.7 \%$ in 2013 and $1.1 \%$ in 2014 . The only reason this can be possible is that large "unallocated" central banks have very high shares of RMB in their reserves and answered with currency decomposition only in the special survey, but not in the COFER. One possible explanation is that China might have reported an aggregate currency decomposition including Hong Kong and Macao. ${ }^{36}$

Another criterion is International banking liability and International bond outstanding. IMF (2015a) lists that the RMB has reached the number 5 spot with a $1.8 \%$ share. For International Debt Securities Outstanding, China rose from $21^{\text {st }}$ position with a $0.0 \%$ share in 2010 to number 9 with a $0.4 \%$ share in 2015 . Similarly, for issuance of the international debt securities, China rose from $22^{\text {nd }}$ in 2010 to $6^{\text {th }}$ in 2015.

IMF (2015a) also examine cross border payments and trade finance. For the former, RMB rose from number 10 in 2010-11 to number 8 in 2014-15. In the category of Trade Finance (Letters of Credit), RMB rose from number 5 in 2010-11 to number 3 in 201415.

All these pieces of information were aggregated to arrive at the RMB share of $10.92 \%$ in the SDR composition currency.

\section{Concluding Remarks}

In all aspects, the RMB is increasingly qualified to be an international reverse currency. In some indicators, the RMB is in the third position after the USD and the EUR. In some other indicators, its position is much lower, but the rank is rising fast. Table 15 summarizes various rankings of RMB that were discussed in the paper. RMB is ranked between the $3^{\text {rd }}$ (SDR composition share) and the $8^{\text {th }}$ (cross-border payments by SWIFT). $<$ Table 15>

The speed of internationalization of the RMB is policy-driven as much as marketdriven. Domestically, RMT internationalization, to be adopted in the SDR, works to

${ }^{36}$ IMF (2015a) states "The survey was conducted on the same strictly confidential basis as the COFER survey, and any RMB holdings that might have been reported by the Hong Kong Monetary Authority or the Monetary Authority of Macao could not be excluded without revealing confidential information." 
accelerate financial liberalization and to loosen capital controls. ${ }^{37}$ Externally, policies to promote currency swap agreements help both trade finance in RMB and RMB as foreign reserves.

Although "freely usable" and "fully convertible" are not related, "fully convertible" is necessary for completing liberalization of the RMB. Many other countries had a currency crisis when capital controls were abolished, due to large capital inflows and outflows.

Currently, the RMB has two markets: the offshore market in Hong Kong $(\mathrm{CNH})$ and the onshore Shanghai (CNY), which are similar but different, due to capital controls. Similarly, the capital markets onshore and offshore are divided, although the stock markets are linked by Shanghai-Hong Kong Connect.

For the RMB to become truly an international reserve currency, all the capital controls must be removed: that is, the on-shore interest rate and off-shore interest rate of the same maturity become identical, and the price differentials between the on-shore stock prices for domestic investors and the off-shore stock prices for foreign investors disappear. The fact that these arbitrage conditions do not hold shows that foreigners do not have full access to the income streams represented by Chinese securities.

The weakest aspect in the internationalization of the RMB is the role of "store of value." The private sector demanded RMB-denominated assets in the hope of everappreciation. As the RMB entered into the depreciation trend, the demand seems to become lower. Among the central banks, demand for RMB as part of foreign reserves is still very low.

Given the speed of internationalization, these cautions and reservations may become irrelevant. More Asian countries will use RMB as denominations, and manage their currencies so that their currencies would co-move with the Chinese Yuan. (Recall the Frankel-Wei regression section.) Currency swaps may be used to bail out a crisis country. In that sense, we may witness a formation of an RMB bloc soon.

\footnotetext{
${ }^{37}$ Without financial liberalization and the (quasi-)fixed exchange rate would have caused overheating in the domestic economy, given that productivity growth was much faster than the trading partners (see Ito (2006)).
} 


\section{References}

Aizenman, Joshua, 2011. "Hoarding international reserves versus a Pigovian tax-cum-subsidy scheme: Reflections on the deleveraging crisis of 2008-2009, and a cost benefit analysis," Journal of Economic Dynamics and Control, vol. 35(9), September: 1502-1513.

Aizenman, Joshua, 2015. "Internationalization of the RMB, Capital Market Openness and Financial Reforms in China," Pacific Economic Review, vol. 20(3): 444-460.

Aizenman, Joshua; Yin-Wong Cheung and Hiro Ito, 2015. "International reserves before and after the global crisis: Is there no end to hoarding?," Journal of International Money and Finance, vol. 52(C): 102-126.

Aizenman, Joshua \& Michael Hutchison, 2012. "Exchange market pressure and absorption by international reserves: Emerging markets and fear of reserve loss during the 2008-2009 crisis," Journal of International Money and Finance, vol. 31(5): 1076-1091.

Aizenman, Joshua and Hiro Ito, 2014. "The More Divergent, the Better? Lessons on Trilemma Policies and Crises for Asia," Asian Development Review, vol. 31(2), September: 21-54.

Aizenman, Joshua and Gurmain Pasricha, 2013. "Why do emerging markets liberalize capital outflow controls? Fiscal versus net capital flow concerns," Journal of International Money and Finance, vol. 39(C): pages 28-64.

Aizenman, Joshua., and Gurmain Pasricha, 2010. Selective swap arrangements and the global financial crisis: Analysis and interpretation. International Review of Economics and Finance, vol. 3: 353-365.

Aizenman, Joshua and Yi Sun, 2012. "The financial crisis and sizable international reserves depletion: From 'fear of floating' to the 'fear of losing international reserves'?," International Review of Economics \& Finance, vol. 24(C): 250-269.

Aizenman, Joshua \& Jinjarak, Yothin \& Park, Donghyun, 2011. "International reserves and swap lines: Substitutes or complements?," International Review of Economics \& Finance, January, vol. 20(1): 5-18.

Bank of International Settlements, 2013. Triennial Central Bank Survey: Foreign exchange turnover in April 2013" Basel, Switzerland, September 2013.

Bank of International Settlements, 2016. Triennial Central Bank Survey: Foreign exchange turnover in April 2013" Basel, Switzerland, September 2016.

Bénassy-Quéré, Agnès and Damien Capelle, 2012. "On the inclusion of the Chinese renminbi in the SDR basket." Documents de travail du Centre d'Economie de la Sorbonne 2012.79 - ISSN : 1955-611X. 2012.

Chen, Hongyi; Wensheng Peng and Chang Shu, 2009. "The potential of the renminbi as an international currency: what we can learn from international experience" in Bank of 
International Settlements, BoK-BIS Seminar on currency internationalisation: Lessons from the global financial crisis and prospects for the future in Asia and the Pacific, 19-20 March 2009. [available at http://www.bis.org/arp/conf 0903.htm]

Chinn, Menzie and Jeffrey Frankel, (2005), "Will the Euro Eventually Surpass the Dollar as Leading International Reserve Currency?” NBER working paper no. 11510, August.

Chinn, Menzie D. and Hiro Ito (2008). "A New Measure of Financial Openness". Journal of Comparative Policy Analysis, Volume 10, Issue 3, p. 309 - 322 (September).

Chinn, Menzie D. and Hiro Ito (2016). "The Chinn-Ito Index - A de jure measure of financial openness" http://web.pdx.edu/ ito/Chinn-Ito website.htm. (Accessed on July 3, 2016).

Cohen, Benjamin J. (1971), The Future of Sterling as an International Currency (London: Macmillan.

Council on Foreign Relations, (2016). "Central Bank Currency Swaps," on CFR website. $\mathrm{http} / /$ www.cfr.org/international-finance/central-bank-currency-swaps-since-financialcrisis/p36419/\#!/?cid=otr-marketing_use-currency_swaps. (Download Sept. 12, 2016)

Dominguez, Kathryn; Hashimoto, Yuko; and Ito, Takatoshi, (2012) "International Reserves and the Global Financial Crisis" Journal of International Economics, vol. 88, issue 2, November: 388-406.

Fernandez, A.; M. Klein, A. Rebucci, M. Schindler and M. Uribe, (2105). "Capital Control Measures: A New Dataset" IMF Working Paper, WP/15/80. April 2015.

Gao, Haihong and Yongding Yu (2009), "Internationalisation of the renminbi", in Bank of International Settlements, BoK-BIS Seminar on currency internationalisation: Lessons from the global financial crisis and prospects for the future in Asia and the Pacific, 19-20 March 2009. [available at http://www.bis.org/arp/conf 0903.htm]

Genberg, Hans (2009), "Currency internationalisation: analytical and policy issues" in Bank of International Settlements, BoK-BIS Seminar on currency internationalisation: Lessons from the global financial crisis and prospects for the future in Asia and the Pacific, 19-20 March 2009. [available at http://www.bis.org/arp/conf 0903.htm]

Goldberg, Linda S.; Craig Kennedy, and Jason Miu, (2011), "Central Bank Dollar Swap Lines and Overseas Dollar Funding Costs," FRBNY Economic Policy Review / May: 3-20.

Grassman Sven. 1973. "A fundamental symmetry in international payments." Journal of International Economics 3: 105-16.

Grassman Sven. 1976. "Currency distribution and forward cover in foreign trade." Journal of International Economics 6: 215-221.

Hong Kong Monetary Authority (HKMA), (2016), HONG KONG: The Global Offshore Renminbi Business Hub. Hong Kong. January.

http://www.hkma.gov.hk/media/eng/doc/key-functions/monetary-stability/rmb-business- 
in-hong-kong/hkma-rmb-booklet.pdf

Huang, Yukon and Clare Lynch, (2013). "Does Internationalizing the RMB Make Sense for China?" Cato Journal, vol. 33, no. 3 (Fall 2013): 571-555.

International Monetary Fund (2011), "Criteria for Broadening the SDR Currency Basket," Prepared by the Finance and Strategy, Policy, and Review Departments, September 23.

International Monetary Fund, (2015a), "Review of the Method and Valuation of the SDR"

November 13, 2015. http://www.imf.org/external/np/pp/eng/2015/111315.pdf

International Monetary Fund (2015 b), "Press Release: IMF Executive Board Completes the 2015

Review of SDR Valuation" December 1.

https://www.imf.org/external/np/sec/pr/2015/pr15543.htm

Ito, Takatoshi, (2006), "Robust Monetary Framework for China," China \& World Economy, vol.

14, No. 5, 2006: 32-47. Illustrated the parallel between Japan and China at 2005.

Ito, Takatoshi, (2007), "Asian Currency Crisis and the IMF, Ten Years Later: Overview” Asian Economic Policy Review, vol. 2, no. 1, June 2007: 16-49.

Ito, Takatoshi, (2008). "Influence of the Renminbi on Exchange Rate Policies of Other Asian Currencies" in Goldstein, Morris and Nicholas R. Lardy (eds.), Debating China's Exchange Rate Policy, Washington, DC: Peterson Institute for International Economics, April: 239-258.

Ito, Takatoshi (2010a), "Fire, Flood, and Lifeboats: Policy Responses to the Global Crisis of 2007-

09, in Federal Reserve Bank of San Francisco (ed.), Asia and the Global Financial Crisis, San Francisco: 207-249.

Ito, Takatoshi, (2010b), "China as Number One: How about the Renminbi?" Asian Economic Policy Review, vol. 5, No. 2: 249-276.

Ito, Takatoshi (2011), “The Internationalization of the RMB: Opportunities and Pitfalls," Council on Foreign Relations, CGS-IIGG Working Paper 15, November 2011.

http://www.cfr.org/china/internationalization-rmb-opportunities-pitfalls/p26287

Ito, Takatoshi, (2012) "Can Asia Overcome the IMF Stigma?” American Economic Review, vol. 102, no.3: 198-202.

Ito, Takatoshi; Satoshi Koibuchi; Kiyotaka Sato; and Junko Shimizu (2012), "The Choice of an Invoicing Currency by Globally Operating Firms: A Firm-Level Analysis of Japanese Exporters" International Journal of Finance and Economics, vol. 17 (4), October: 305-320.

Kawai, Masahiro and Victor Pontines, (2016). "Is there really a renminbi bloc in Asia?: Modified Frankel-Wei Approach,” Journal of International Money and Finance, vol. 62, December: 72-97.

Kenen, Peter, (1983): "The Role of the dollar as an international currency," Group of Thirty Occasional Papers, no. 13, New York. 
Kenen, Peter, (2009). "Currency internationalisation: an overview" in Bank of International Settlements, BoK-BIS Seminar on currency internationalisation: Lessons from the global financial crisis and prospects for the future in Asia and the Pacific, 19-20 March 2009. [available at http://www.bis.org/arp/conf_0903.htm]

Kitano, Naohiro and Yukinori Harada, 2014. “Estimating China's Foreign Aid 2001-2013," JICA Research Institute Working Paper, no. 78, June.

Klein, Michael W., 2012. "Capital Controls: Gates versus Walls," Brookings Papers on Economic Activity 2012 (Fall): 317-355.

McKinnon Ronald, 1979. Money in International Exchange: The Convertible Currency System, Oxford University Press: Oxford, UK.

Moss, Frank (2009), "The Euro: Internationalised at birth," in Bank of International Settlements, BoK-BIS Seminar on currency internationalisation: Lessons from the global financial crisis and prospects for the future in Asia and the Pacific, 19-20 March 2009. [available at http://www.bis.org/arp/conf 0903.htm]

Park, Yung Chul and Kwanho Shin, 2009. "Internationalisation of currency in East Asia: implications for regional monetary and financial cooperation" in Bank of International Settlements, BoK-BIS Seminar on currency internationalisation: Lessons from the global financial crisis and prospects for the future in Asia and the Pacific, 19-20 March 2009. [available at http://www.bis.org/arp/conf_0903.htm]

Renmin University of China, International Monetary Institute, 2016. RMB Internationalization Report 2016: Currency Internationalization and Macro Risk Management, Beijin July 24. http://www.imi.org.cn/report/19770.

Sussangkarn, Chalongphob, 2011. "Chiang Mai Initiative multilateralization: Origin, Development, and Outlook," AEPR, vol. 6: 203-220.

SWIFT (2016). "Internationalisation of the Renminbi: Measuring Progress Towards a Global Currency,” RMB Tracker, July 2016 Edition.

swift_bi_rmbtracker_july2016_en.pdf.pdf (Accessed July 23, 2016)

SWIFT (various issues). RMB Tracker (past issues) available at https://www.swift.com/oursolutions/compliance-and-shared-services/business-intelligence/renminbi/rmbtracker/document-centre\#topic-tabs-menu

Zhou, Xiaochuan. 2009. Reform the international monetary system. March 23, 2009. http://www.pbc.gov.cn/english/130724/2842945/index.html (Last accessed September 1, 2016). 
Table 1: Monetary and Forex Regimes in Asia

\begin{tabular}{|c|c|c|c|c|c|}
\hline Country & $\begin{array}{l}\text { Income Group } \\
\text { (fn1) }\end{array}$ & $\begin{array}{l}\text { Exchange Rate Regime } \\
\text { (fn 2) }\end{array}$ & $\begin{array}{l}\text { Monetary Policy Target (fn 3), } \\
\text { with inflation target being for } \\
2016\end{array}$ & $\begin{array}{l}\text { Capital } \\
\text { Controls (fn 4) }\end{array}$ & $\begin{array}{l}\text { Chinn-lto } \\
\text { Openness Index } \\
\text { for } 2014 \text { (fn5) }\end{array}$ \\
\hline Japan & High & Free Floating & Inflation Targeting $2 \%$ & Open & 1.000 \\
\hline China & Upper Middle & Crawling Peg (USD) & & Wall & 0.165 \\
\hline Korea & High & Floating & Inflation Targeting $2 \%$ & Open & 0.716 \\
\hline Taiwan & Upper Middle & Floating & M2 growth $2.5-6.5 \%$ & Open & NA \\
\hline Hong Kong & High & Currency Board (USD) & Currency Board (USD) & Open & 1.000 \\
\hline Indonesia & Lower Middle & Floating & Inflation Targeting $4 \% \pm 1 \%$ & Gate & 0.413 \\
\hline Thailand & Upper Middle & Floating & Inflation Targeting $2.5 \% \pm 1.5 \%$ & Gate & 0.165 \\
\hline Malaysia & Upper Middle & Managed (CHY) & & Wall & 0.413 \\
\hline Singapore & High & Basket Currency & (exchange rate targeting) & Open & 1.000 \\
\hline Philippines & Lower Middle & Floating & Inflation targeting $3 \% \pm 1 \%$ & Wall & 0.449 \\
\hline Brunei & High & Currency Board (SGD) & Currency Board (SGD) & Open & NA \\
\hline Cambodia & Low & managed (USD) & (dollarization) & Open & 0.716 \\
\hline Lao Rep. & Low & Crawling Peg (USD) & (dollarization) & Wall & 0.165 \\
\hline Myanmar & Low & managed (USD) & (dollarization) & Gate & 0.000 \\
\hline Vietnam & Lower Middle & Basket Currency & & Gate & 0.413 \\
\hline
\end{tabular}

Source: Author's creation 
Figure 1: The CNY/USD exchange rate. January 2000 - June 2016

\section{CNY/USD, $2000.01-2016.06$}

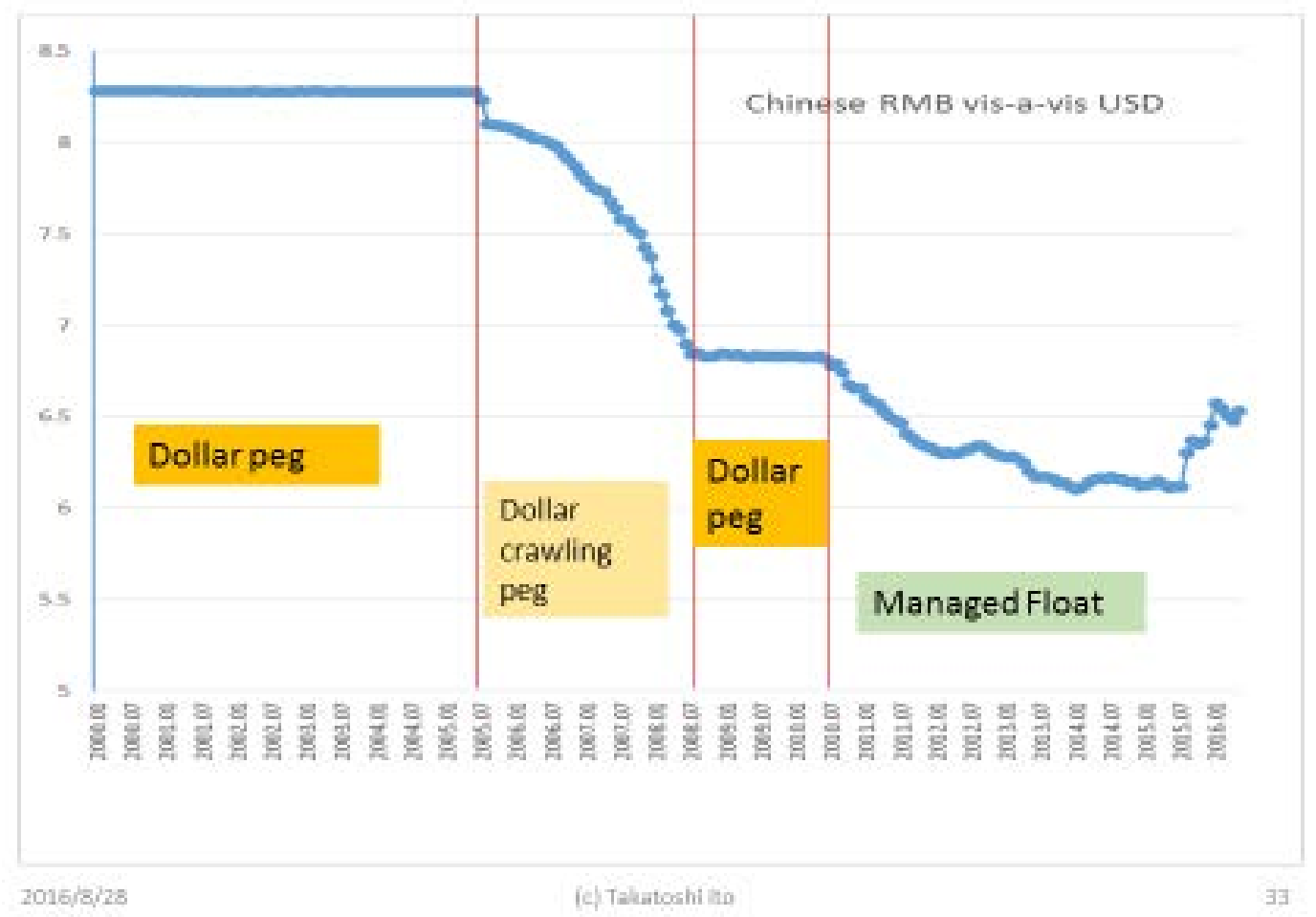


Figure 2

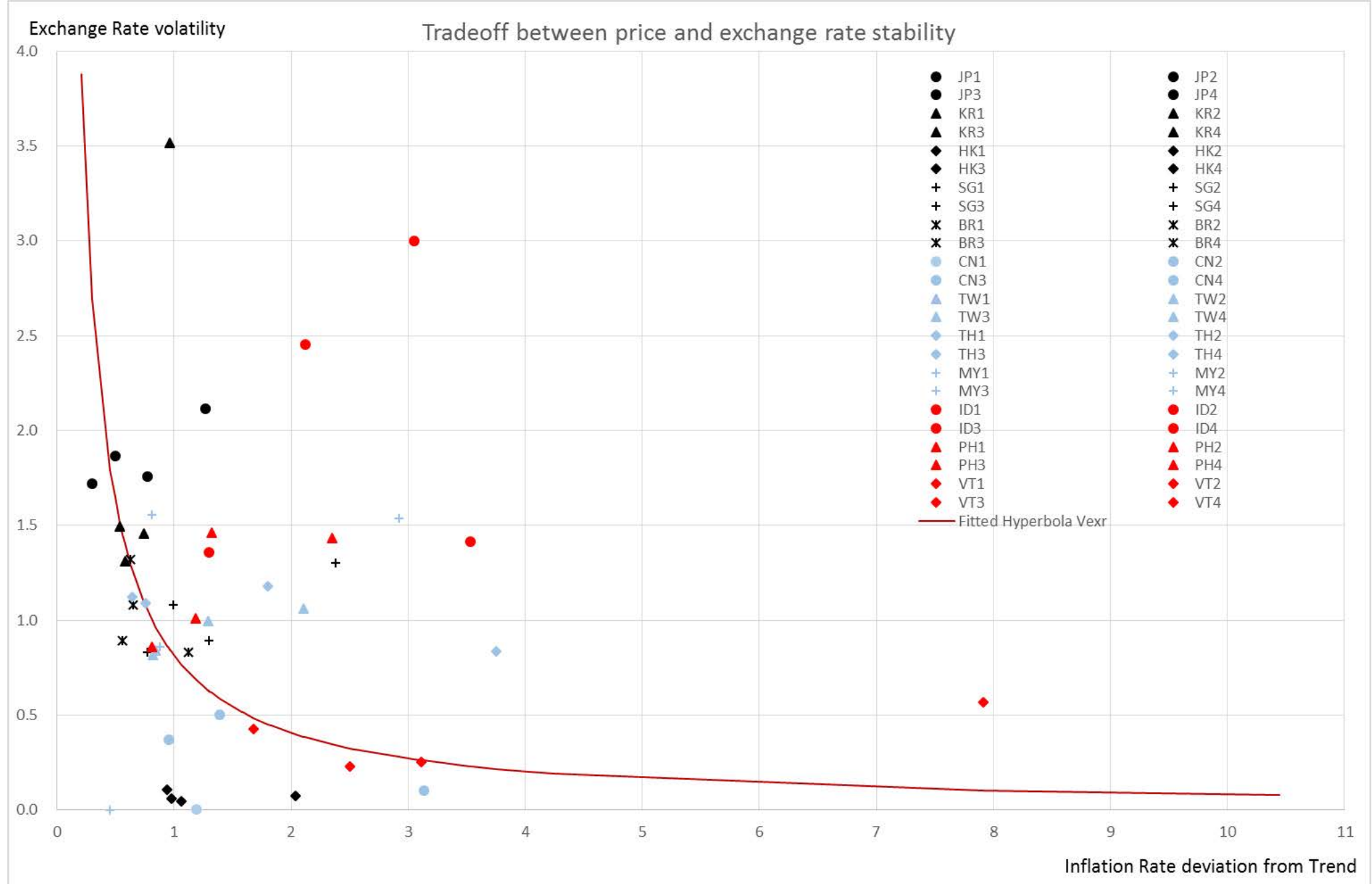


Figure 3

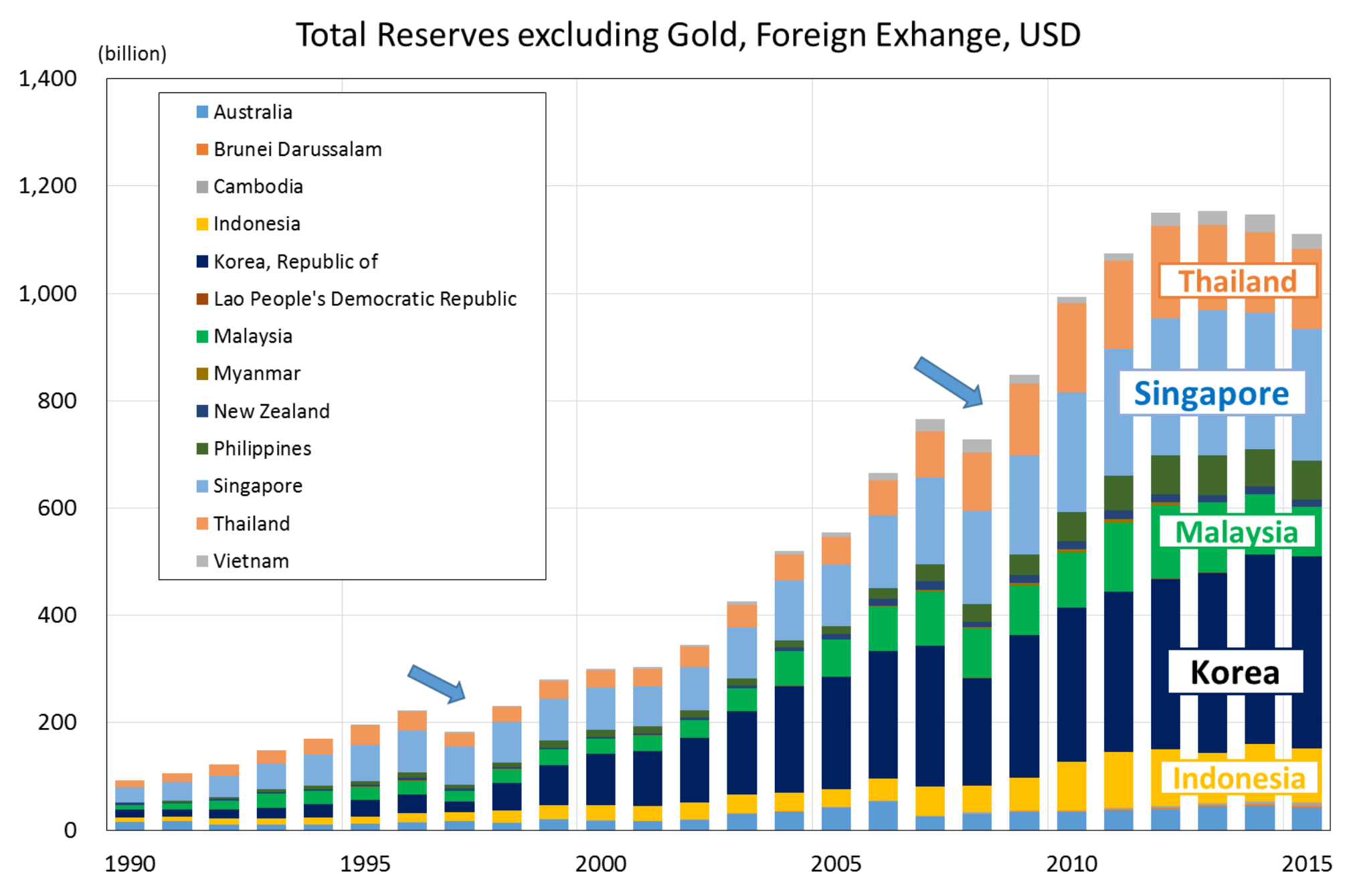


Table 2: Six aspects of an international currency

\section{Dimensions of an International Currency}

\begin{tabular}{|c|c|c|}
\hline & Private Sector & Official Sector \\
\hline \multirow{4}{*}{ Unit of account } & Trade invoicing $<\mathrm{RMB}$ trade invoicing $>$ & Being pegged by other countries $<$ China. None $>$ \\
\hline & $\begin{array}{l}\text { Denomination of financial products issued by companies } \\
\text { and financial institutions of other countries }<\text { China. } \\
\text { Panda bonds }>\end{array}$ & $\begin{array}{l}\text { High weights in (official or de facto) currency baskets of } \\
\text { foreign central banks }<\text { China. Frankel-Wei regression }>\end{array}$ \\
\hline & $\begin{array}{l}\text { Denomination of offshore financial products by domestic } \\
\text { companies }<\text { China. Dim Sum bond }>\end{array}$ & (IMF) SDR composition currency <China. Oct. 2016> \\
\hline & & $\begin{array}{l}\text { Denomination of international bonds issued by other } \\
\text { governments or IFIs }\end{array}$ \\
\hline \multirow{4}{*}{$\begin{array}{l}\text { Medium of exchange } \\
\text { (Settlement) }\end{array}$} & Trade settlement $<$ China. RMB trade settlement $>$ & Intervention currency by other monetary authorities \\
\hline & \multirow{3}{*}{$\begin{array}{l}\text { International financial transaction settlement }<\text { China. } \\
\text { SWIFT }><\text { China. BIS Triennial Survey }>\end{array}$} & Government financial transactions (such as ODA) \\
\hline & & Central Bank swaps currency $<$ China. PBOC Swap lines $>$ \\
\hline & & Currency circulation abroad (e.g., dollarization); \\
\hline \multirow{2}{*}{ Store of value } & Cross-border deposits <China. RMB deposits offshore $>$ & $\begin{array}{l}\text { Foreign reserves (of other countries) }<\text { China. IMF } \\
\text { COFER; \& Special Survey }>\end{array}$ \\
\hline & Cross-border securities investment & Sovereign Wealth Funds (of other countries) \\
\hline
\end{tabular}

Source: Author's creation, slightly modified from Ito (2011), which was based on the matrix first proposed by Kenen (1983) and Cohen (1971) . 
Table 3: SWIF ranking, RMB time series

RMB: SWIFT world payment ranking time series

\begin{tabular}{|c|c|c|}
\hline Month & Ranking & Share \\
\hline June 2016 & $\# 6$ & $1.72 \%$ \\
\hline June 2015 & $\# 5$ & $2.09 \%$ \\
\hline June 2014 & $\# 7$ & $1.55 \%$ \\
\hline January 2014 & $\# 7$ & $1.39 \%$ \\
\hline June 2013 & $\# 11$ & $0.87 \%$ \\
\hline January 2012 & $\# 20$ & $0.25 \%$ \\
\hline October 2010 & $\# 35$ & $\mathrm{NA}$ \\
\hline
\end{tabular}

Source: Author's creation from SWIFT, RMT Tracker, various issues.

Figure 4: SWIFT ranking, June 2016

June 2016

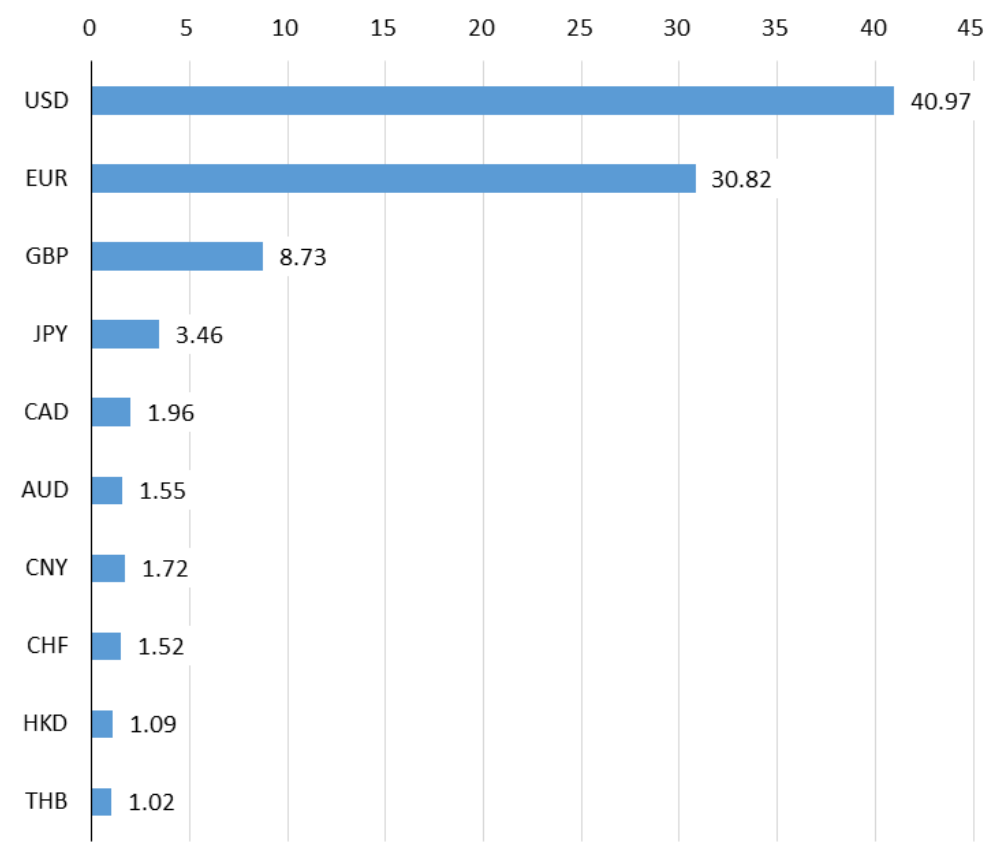

Source: SWIFT, RMT Tracker (July 2016). 
Table 4. BIS Triennial Surveys, 2001-2016

Currency distribution of OTC foreign exchange turnover

Net-net basis, ${ }^{1}$ percentage shares of average daily turnover in April $^{2}$

\begin{tabular}{|c|c|c|c|c|c|c|c|c|c|c|c|c|}
\hline \multirow{2}{*}{ Currency } & \multicolumn{2}{|c|}{2001} & \multicolumn{2}{|c|}{2004} & \multicolumn{2}{|c|}{2007} & \multicolumn{2}{|c|}{2010} & \multicolumn{2}{|c|}{2013} & \multicolumn{2}{|c|}{2016} \\
\hline & Share & Rank & Share & Rank & Share & Rank & Share & Rank & Share & Rank & Share & Rank \\
\hline USD & 89.9 & 1 & 88.0 & 1 & 85.6 & 1 & 84.9 & 1 & 87.0 & 1 & 87.6 & 1 \\
\hline EUR & 37.9 & 2 & 37.4 & 2 & 37.0 & 2 & 39.1 & 2 & 33.4 & 2 & 31.3 & 2 \\
\hline JPY & 23.5 & 3 & 20.8 & 3 & 17.2 & 3 & 19.0 & 3 & 23.1 & 3 & 21.6 & 3 \\
\hline GBP & 13.0 & 4 & 16.5 & 4 & 14.9 & 4 & 12.9 & 4 & 11.8 & 4 & 12.8 & 4 \\
\hline AUD & 4.3 & 7 & 6.0 & 6 & 6.6 & 6 & 7.6 & 5 & 8.6 & 5 & 6.9 & 5 \\
\hline CAD & 4.5 & 6 & 4.2 & 7 & 4.3 & 7 & 5.3 & 7 & 4.6 & 7 & 5.1 & 6 \\
\hline $\mathrm{CHF}$ & 6.0 & 5 & 6.0 & 5 & 6.8 & 5 & 6.3 & 6 & 5.2 & 6 & 4.8 & 7 \\
\hline $\mathrm{CNY}^{3}$ & 0.0 & 35 & 0.1 & 29 & 0.5 & 20 & 0.9 & 17 & 2.2 & 9 & 4.0 & 8 \\
\hline SEK & 2.5 & 8 & 2.2 & 8 & 2.7 & 9 & 2.2 & 9 & 1.8 & 11 & 2.2 & 9 \\
\hline$M X N^{3}$ & 0.8 & 14 & 1.1 & 12 & 1.3 & 12 & 1.3 & 14 & 2.5 & 8 & 2.2 & 10 \\
\hline$N_{Z} D^{3}$ & 0.6 & 16 & 1.1 & 13 & 1.9 & 11 & 1.6 & 10 & 2.0 & 10 & 2.1 & 11 \\
\hline$S_{G} D^{3}$ & 1.1 & 12 & 0.9 & 14 & 1.2 & 13 & 1.4 & 12 & 1.4 & 15 & 1.8 & 12 \\
\hline $\mathrm{HKD}^{3}$ & 2.2 & 9 & 1.8 & 9 & 2.7 & 8 & 2.4 & 8 & 1.4 & 13 & 1.7 & 13 \\
\hline $\mathrm{NOK}^{3}$ & 1.5 & 10 & 1.4 & 10 & 2.1 & 10 & 1.3 & 13 & 1.4 & 14 & 1.7 & 14 \\
\hline $\mathrm{KRW}^{3}$ & 0.8 & 15 & 1.1 & 11 & 1.2 & 14 & 1.5 & 11 & 1.2 & 17 & 1.6 & 15 \\
\hline
\end{tabular}

Source: Bank of International Settlements, Triennial Survey, 2016. 
Figure 5 RMB deposits in Hong Kong Banking System

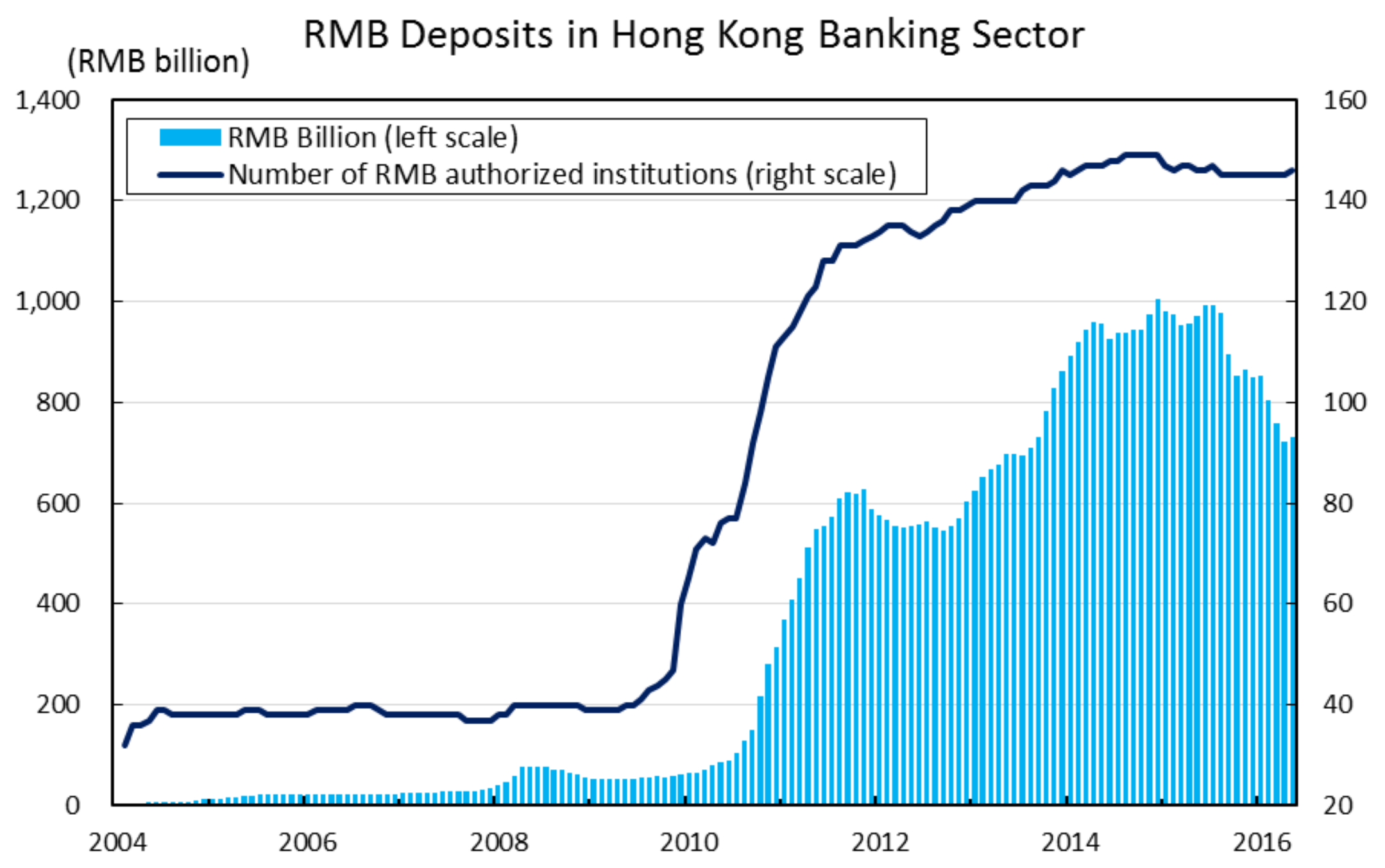

Source: Hong Kong Monetary Authority 
Table 5: RMB deposits

$\Delta$ RMBDEPO $_{t}=\mathrm{c}_{1}+\mathrm{c}_{2} \Delta \mathrm{CNYUSD}_{t-1}+\mathrm{c}_{3} \Delta N$ Bank $_{t-1}+\varepsilon_{t}$

\begin{tabular}{|c|c|c|c|c|c|}
\hline & & Eq 1 & Eq 2 & Eq 3 & Eq 4 \\
\hline & & $\begin{array}{l}2004 M 4- \\
2016 M 5\end{array}$ & $\begin{array}{l}\text { 2010M7- } \\
\text { 2016M5 }\end{array}$ & $\begin{array}{l}\text { 2004M4 - } \\
2016 \mathrm{M} 5\end{array}$ & $\begin{array}{l}\text { 2010M7- } \\
2016 M 5\end{array}$ \\
\hline & & All & Post-GFC & All & Post-GFC \\
\hline \multirow[t]{2}{*}{$c(1)$} & Coeff & $0.0186 * \star \star$ & 0.0055 & $0.0299 * \star \star$ & $0.0288 * * *$ \\
\hline & STDERR & 0.0064 & 0.0077 & 0.0066 & 0.0091 \\
\hline \multirow[t]{2}{*}{$c(2)$} & Coeff & $-4.5407 * \star \star *$ & -2.8182 ** & $-5.1106 * \star \star$ & $-5.6065 * \star *$ \\
\hline & STDERR & 1.1392 & 1.2633 & 1.2398 & 1.5653 \\
\hline \multirow[t]{5}{*}{$c(3)$} & Coeff & $0.0159 \star \star \star \star$ & $0.0261 * * *$ & & \\
\hline & STDERR & 0.0029 & 0.0037 & & \\
\hline & N Obs & 146 & 69 & 146 & 69 \\
\hline & Adjusted R-sq & 0.2461 & 0.4976 & 0.0993 & 0.1446 \\
\hline & DW & 0.9263 & 1.5596 & 0.6414 & 0.6011 \\
\hline
\end{tabular}

Note: $* * *, * *$, and $*$ denote significant $1 \%, 5 \%, 10 \%$ level. 
Figure 6: AH Premium and YH Premium

\section{YHPremium \& AHPremium}

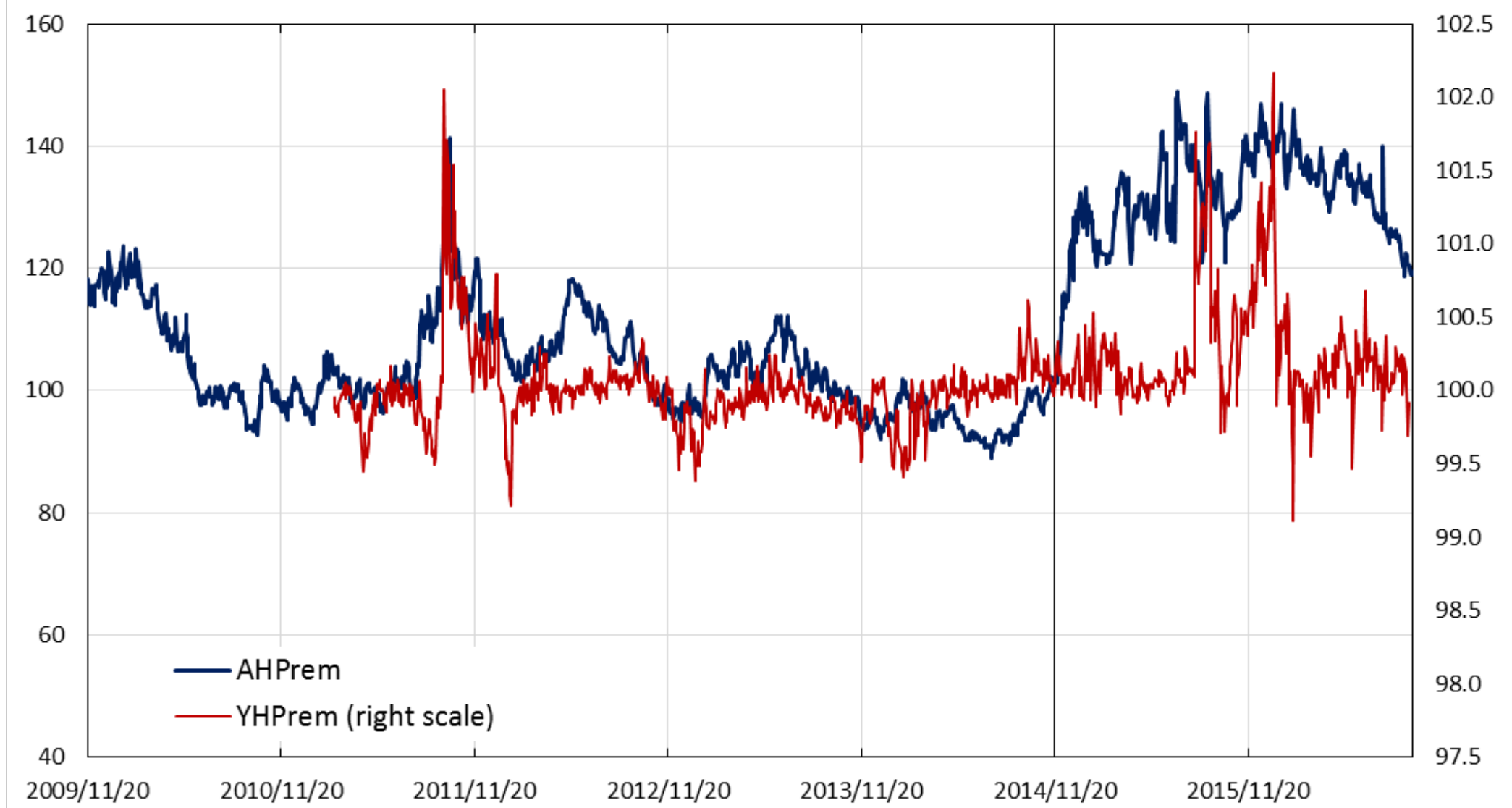

Notes:

AH Premium is published by Hang Seng Index and freely available vis Bloomberg and other information outlet.

YH Premium is defined and calculated by the author from CNYUSD and CNHUSD, the data of the exchange rates are taken from DataStream. 
Table 6: Accessibility of Chinese equities for foreigners

\begin{tabular}{|l|l|l|l|}
\hline & Stock Connect & QFII & RQFII \\
\hline \multirow{2}{*}{ Eligible Investor } & $\begin{array}{l}\text { SSE Members, institutional } \\
\text { investors \& individual } \\
\text { investors* in Mainland for HK } \\
\text { Stock Connect trades }\end{array}$ & Selected institutional investors & Selected institutional investors \\
\cline { 2 - 3 } & $\begin{array}{l}\text { All Hong Kong and overseas } \\
\text { investors for Shanghai Stock } \\
\text { Connect trades }\end{array}$ & & \\
\hline Currency & Transactions in RMB & $\begin{array}{l}\text { Transactions in USD and other } \\
\text { foreign currencies }\end{array}$ & Transactions in RMB \\
\hline Quota & Applies to market as a whole & $\begin{array}{l}\text { Allocated to each } \\
\text { institutional investor }\end{array}$ & Allocated to offshore regions \\
\hline Eligible Products & $\begin{array}{l}\text { Selected A-listed and H-listed } \\
\text { Stocks }\end{array}$ & $\begin{array}{l}\text { RMB denominated products } \\
\text { approved by CSRC** }\end{array}$ & $\begin{array}{l}\text { RMB denominated products } \\
\text { approved by CSRC }\end{array}$ \\
\hline Regulation of Funds & $\begin{array}{l}\text { Funds must return to origin; } \\
\text { No lock up period }\end{array}$ & $\begin{array}{l}\text { Funds subject to lock up } \\
\text { period and can stay in } \\
\text { mainland afterwards }\end{array}$ & $\begin{array}{l}\text { Funds subject to lock up } \\
\text { period and can stay in } \\
\text { mainland afterwards }\end{array}$ \\
\hline Investors' Rights & Subject to limitations*** & No limitations & No limitations \\
\hline $\begin{array}{l}\text { *Individual investors must have balance of at least 500,000 in their cash and securities accounts. } \\
\text { **Stocks, bonds, warrants, funds, index futures fixed income products in interbank-market; primary market activities such as } \\
\text { IPO, convertible bond issuance, additional shares issuance and seasoned equity offerings. } \\
* * * \text { Shares acquired as entitlements can only be sold if they are not one of the eligible stocks of the Stock Connect but are SSE- } \\
\text { listed and cannot be bought or sold using the Stock Connect scheme if they are not SSE-listed. }\end{array}$ \\
\hline
\end{tabular}

Source: http://english.sse.com.cn/investors/shhkconnect/introduction/comparing/ 
Table 7. Asia currency basket weights, CHF base. Periods II and IV

\begin{tabular}{|c|c|c|c|c|c|c|c|c|}
\hline & & $\begin{array}{l}\text { /2005 - 7/18 } \\
\text { servations: }\end{array}$ & & & & $\begin{array}{l}\text { /2010 - 6/24 } \\
\text { servations: }\end{array}$ & & \\
\hline & Coefficient & Std. Error & Prob. & & Coefficient & Std. Error & Prob. & \\
\hline Indonesia & & & & & & & & \\
\hline$\beta_{1}$ & 0.7183 & 0.1765 & 0.0001 & *** & 0.2581 & 0.0769 & 0.0008 & *** \\
\hline$\beta$ & 0.2421 & 0.0477 & 0.0000 & $* * *$ & 0.0509 & 0.0161 & 0.0016 & $* * *$ \\
\hline$\beta_{3}$ & 0.0873 & 0.1788 & 0.6256 & & 0.7180 & 0.0751 & 0.0000 & $* * *$ \\
\hline & Iared: & 0.4198 & & & & 0.7842 & & \\
\hline & stat: & 2.1722 & & & & 1.8813 & & \\
\hline Korea & & & & & & & & \\
\hline$\beta_{1}$ & 0.4883 & 0.1297 & 0.0002 & $* * *$ & -0.0654 & 0.0985 & 0.5069 & \\
\hline$\beta_{2}$ & 0.1702 & 0.0351 & 0.0000 & $* * *$ & 0.3080 & 0.0206 & 0.0000 & $* * *$ \\
\hline$\beta_{3}$ & 0.4061 & 0.1314 & 0.0021 & $* * *$ & 0.7176 & 0.0962 & 0.0000 & *** \\
\hline & Iared: & 0.6199 & & & & 0.6416 & & \\
\hline & stat: & 1.9716 & & & & 2.1353 & & \\
\hline Malaysia & & & & & & & & \\
\hline$\beta_{1}$ & 0.5028 & 0.0996 & 0.0000 & *** & -0.2213 & 0.0923 & 0.0166 & $* *$ \\
\hline$\beta_{2}$ & 0.1272 & 0.0269 & 0.0000 & $* * *$ & 0.1597 & 0.0193 & 0.0000 & *** \\
\hline$\beta_{3}$ & 0.3871 & 0.1009 & 0.0001 & $* * *$ & 1.1273 & 0.0901 & 0.0000 & $* * *$ \\
\hline & Iared: & 0.7256 & & & & 0.6988 & & \\
\hline & stat: & 2.4820 & & & & 2.0048 & & \\
\hline P hilippines & & & & & & & & \\
\hline$\beta_{1}$ & 0.7703 & 0.1372 & 0.0000 & $* * *$ & 0.3786 & 0.0638 & 0.0000 & *** \\
\hline$\beta_{2}$ & 0.1007 & 0.0371 & 0.0068 & $* * *$ & 0.1432 & 0.0134 & 0.0000 & $* * *$ \\
\hline$\beta_{3}$ & 0.1592 & 0.1390 & 0.2525 & & 0.4960 & 0.0623 & 0.0000 & $* * *$ \\
\hline & Iared: & 0.5930 & & & & 0.8306 & & \\
\hline & stat: & 2.2712 & & & & 2.0531 & & \\
\hline Singapore & & & & & & & & \\
\hline$\beta_{1}$ & 0.3195 & 0.0659 & 0.0000 & *** & 0.2119 & 0.0648 & 0.0011 & $* * *$ \\
\hline$\beta_{2}$ & 0.2376 & 0.0178 & 0.0000 & $* * *$ & 0.2819 & 0.0136 & 0.0000 & $* * *$ \\
\hline$\beta_{3}$ & 0.4122 & 0.0667 & 0.0000 & $* * *$ & 0.4028 & 0.0633 & 0.0000 & *** \\
\hline & Iared: & 0.8224 & & & & 0.7977 & & \\
\hline & stat: & 2.3371 & & & & 2.2111 & & \\
\hline Thailand & & & & & & & & \\
\hline$\beta_{1}$ & 0.5046 & 0.2046 & 0.0139 & $* *$ & 0.4703 & 0.0553 & 0.0000 & $* * *$ \\
\hline$\beta_{2}$ & 0.1227 & 0.0553 & 0.0268 & $* *$ & 0.1662 & 0.0116 & 0.0000 & *** \\
\hline$\beta_{3}$ & 0.3541 & 0.2073 & 0.0880 & $*$ & 0.3198 & 0.0540 & 0.0000 & $* * *$ \\
\hline & Iared: & 0.3641 & & & & 0.8559 & & \\
\hline & stat: & 2.3052 & & & & 1.8789 & & \\
\hline
\end{tabular}

Note: ${ }^{* *}, * *$, and $*$ denote significant $1 \%, 5 \%, 10 \%$ level.

Note: Author's calculation 
Table 8: Asia currency basket weights, CHF base. Periods IV-1 and IV-2

\begin{tabular}{|c|c|c|c|c|c|c|c|c|}
\hline \multirow{3}{*}{ Indonesia } & \multicolumn{4}{|c|}{$\begin{array}{l}\text { 6/16/2010 - 1/14/2014 } \\
\text { ( observations: } 935 \text { ) }\end{array}$} & \multicolumn{4}{|c|}{$\begin{array}{l}\text { 1/15/2014 - 6/24/2016 } \\
\text { ( observations: } 638 \text { ) }\end{array}$} \\
\hline & \multirow[t]{2}{*}{ Coefficient } & \multirow[t]{2}{*}{ Std. Error } & \multicolumn{2}{|l|}{ Prob. } & \multirow[t]{2}{*}{ Coefficient } & \multirow[t]{2}{*}{ Std. Error } & \multicolumn{2}{|l|}{ P rob. } \\
\hline & & & & & & & & \\
\hline$\beta_{1}$ & 0.4647 & 0.1065 & 0.0000 & $* * *$ & 0.1473 & 0.1172 & 0.2095 & \\
\hline$\beta_{2}$ & 0.0555 & 0.0174 & 0.0015 & $* * *$ & 0.0566 & 0.0318 & 0.0762 & $*$ \\
\hline$\beta_{3}$ & 0.4974 & 0.1061 & 0.0000 & $* * *$ & 0.8413 & 0.1115 & 0.0000 & *** \\
\hline & Adjusted R-squared: & 0.8280 & & & & 0.7342 & & \\
\hline & Durbin-Watson stat: & 1.9754 & & & & 1.8101 & & \\
\hline \multicolumn{9}{|l|}{ Korea } \\
\hline$\beta_{1}$ & -0.1551 & 0.1574 & 0.3246 & & -0.0541 & 0.1289 & 0.6746 & \\
\hline$\beta_{2}$ & 0.3176 & 0.0257 & 0.0000 & $* * *$ & 0.2611 & 0.0350 & 0.0000 & $* * *$ \\
\hline$\beta_{3}$ & 0.8574 & 0.1569 & 0.0000 & $* * *$ & 0.6443 & 0.1226 & 0.0000 & $* * *$ \\
\hline & Adjusted R-squared: & 0.6450 & & & & 0.6448 & & \\
\hline & Durbin-Watson stat: & 2.1548 & & & & 2.0619 & & \\
\hline \multicolumn{9}{|l|}{ Malaysia } \\
\hline$\beta_{1}$ & -0.1760 & 0.1269 & 0.1658 & & -0.2070 & 0.1412 & 0.1431 & \\
\hline$\beta_{2}$ & 0.1939 & 0.0207 & 0.0000 & *** & 0.1082 & 0.0383 & 0.0049 & $* * *$ \\
\hline$\beta_{3}$ & 1.0385 & 0.1265 & 0.0000 & $* * *$ & 1.1669 & 0.1343 & 0.0000 & $* * *$ \\
\hline & Adjusted R-squared: & 0.7534 & & & & 0.6419 & & \\
\hline & Durbin-Watson stat: & 2.0638 & & & & 1.9492 & & \\
\hline \multicolumn{9}{|l|}{ Philippines } \\
\hline$\beta_{1}$ & 0.1693 & 0.1123 & 0.1319 & & 0.5127 & 0.0711 & 0.0000 & $* * *$ \\
\hline$\beta_{2}$ & 0.1535 & 0.0183 & 0.0000 & $* * *$ & 0.1164 & 0.0193 & 0.0000 & $* * *$ \\
\hline$\beta_{3}$ & 0.6961 & 0.1119 & 0.0000 & $* * *$ & 0.3788 & 0.0677 & 0.0000 & $* * *$ \\
\hline & Adjusted R-squared: & 0.7959 & & & & 0.8789 & & \\
\hline & Durbin-Watson stat: & 2.0719 & & & & 2.0029 & & \\
\hline \multicolumn{9}{|l|}{ Singapore } \\
\hline$\beta_{1}$ & 0.2386 & 0.1050 & 0.0232 & ** & 0.2278 & 0.0831 & 0.0063 & $* * *$ \\
\hline$\beta_{2}$ & 0.3255 & 0.0171 & 0.0000 & $* * *$ & 0.2043 & 0.0226 & 0.0000 & $* * *$ \\
\hline$\beta_{3}$ & 0.3453 & 0.1046 & 0.0010 & $* * *$ & 0.4254 & 0.0790 & 0.0000 & $* * *$ \\
\hline & Adjusted R-squared: & 0.7840 & & & & 0.8191 & & \\
\hline & Durbin-Wats on stat: & 2.1965 & & & & 2.1918 & & \\
\hline \multicolumn{9}{|l|}{ Thailand } \\
\hline$\beta_{1}$ & 0.4258 & 0.0928 & 0.0000 & $* * *$ & 0.5252 & 0.0670 & 0.0000 & $* * *$ \\
\hline$\beta_{2}$ & 0.2036 & 0.0152 & 0.0000 & *** & 0.0971 & 0.0182 & 0.0000 & *** \\
\hline$\beta_{3}$ & 0.3368 & 0.0925 & 0.0003 & $* * *$ & 0.3011 & 0.0637 & 0.0000 & $* * *$ \\
\hline & Adjusted R-squared: & 0.8343 & & & & 0.8856 & & \\
\hline & Durbin-Wats on stat: & 1.8664 & & & & 1.8677 & & \\
\hline
\end{tabular}

Note: $* * * * *$, and $*$ denote significant $1 \%, 5 \%, 10 \%$ level.

Note: Author's calculation 
Table 9. Asia currency basket weights, NZD base, periods II and IV

\begin{tabular}{|c|c|c|c|c|c|c|c|c|}
\hline & & $\begin{array}{l}\text { /2005 - 7/18 } \\
\text { senvations: }\end{array}$ & & & & $\begin{array}{l}\text { /2010 - 6/2 } \\
\text { senvations: }\end{array}$ & & \\
\hline & Coefficient & Std. Error & Prob. & & Coefficient & Std. Error & Prob. & \\
\hline Indonesia & & & & & & & & \\
\hline$\beta_{1}$ & -0.0394 & 0.0486 & 0.4180 & & 0.0436 & 0.0102 & 0.0000 & $* * *$ \\
\hline$\beta_{2}$ & 0.1942 & 0.0881 & 0.0278 & $* *$ & -0.0041 & 0.0149 & 0.7832 & \\
\hline$\beta_{3}$ & 0.7704 & 0.0687 & 0.0000 & $* * *$ & 0.9750 & 0.0184 & 0.0000 & $* * *$ \\
\hline & lared: & 0.5527 & & & & 0.7687 & & \\
\hline & stat: & 2.1824 & & & & 1.8971 & & \\
\hline Korea & & & & & & & & \\
\hline$\beta_{1}$ & -0.1117 & 0.0345 & 0.0012 & $* * *$ & 0.1331 & 0.0123 & 0.0000 & $* * *$ \\
\hline$\beta_{2}$ & 0.3328 & 0.0624 & 0.0000 & $* * *$ & 0.0529 & 0.0181 & 0.0036 & $* * *$ \\
\hline$\beta_{3}$ & 0.7224 & 0.0487 & 0.0000 & $* * *$ & 0.7460 & 0.0223 & 0.0000 & $* * *$ \\
\hline & lared: & 0.7137 & & & & 0.5479 & & \\
\hline & stat: & 2.0276 & & & & 2.2042 & & \\
\hline Malaysia & & & & & & & & \\
\hline$\beta_{1}$ & -0.0619 & 0.0269 & 0.0215 & $* *$ & 0.1128 & 0.0118 & 0.0000 & $* * *$ \\
\hline$\beta_{2}$ & 0.2070 & 0.0487 & 0.0000 & $* * *$ & -0.0126 & 0.0173 & 0.4669 & \\
\hline$\beta_{3}$ & 0.7877 & 0.0379 & 0.0000 & $* * *$ & 0.9706 & 0.0213 & 0.0000 & *** \\
\hline & Iared: & 0.8149 & & & & 0.6536 & & \\
\hline & stat: & 2.4942 & & & & 2.0518 & & \\
\hline Philippines & & & & & & & & \\
\hline$\beta_{1}$ & -0.0936 & 0.0377 & 0.0134 & $* *$ & 0.0583 & 0.0084 & 0.0000 & $* * *$ \\
\hline$\beta_{2}$ & 0.2280 & 0.0684 & 0.0009 & $* * *$ & 0.0278 & 0.0123 & 0.0239 & $* *$ \\
\hline$\beta_{3}$ & 0.8173 & 0.0533 & 0.0000 & $* * *$ & 0.8975 & 0.0151 & 0.0000 & $* * *$ \\
\hline & uared: & 0.7073 & & & & 0.8073 & & \\
\hline & stat: & 2.2871 & & & & 2.0525 & & \\
\hline Singapore & & & & & & & & \\
\hline$\beta_{1}$ & 0.0004 & 0.0186 & 0.9827 & & 0.0926 & 0.0086 & 0.0000 & $* * *$ \\
\hline$\beta_{2}$ & 0.1080 & 0.0338 & 0.0014 & $* * *$ & 0.0416 & 0.0126 & 0.0010 & *** \\
\hline$\beta_{3}$ & 0.7584 & 0.0263 & 0.0000 & $* * *$ & 0.7155 & 0.0155 & 0.0000 & $* * *$ \\
\hline & lared: & 0.8985 & & & & 0.7631 & & \\
\hline & stat: & 2.3657 & & & & 2.2891 & & \\
\hline Thailand & & & & & & & & \\
\hline$\beta_{1}$ & -0.0149 & 0.0556 & 0.7894 & & 0.0686 & 0.0074 & 0.0000 & $* * *$ \\
\hline$\beta_{2}$ & 0.0910 & 0.1007 & 0.3665 & & 0.0099 & 0.0109 & 0.3658 & \\
\hline$\beta_{3}$ & 0.8419 & 0.0785 & 0.0000 & $* * *$ & 0.8367 & 0.0134 & 0.0000 & $* * *$ \\
\hline & sared: & 0.5222 & & & & 0.8394 & & \\
\hline & stat: & 2.3205 & & & & 1.8844 & & \\
\hline
\end{tabular}

Note: $* * * * *$, and $*$ denote significant $1 \%, 5 \%, 10 \%$ level.

Note: Author's calculation 
Table 10. Asia currency basket weights, NZD base, Periods IV-1 and IV-2

\begin{tabular}{|c|c|c|c|c|c|c|c|c|}
\hline & & $\begin{array}{l}\text { /2010 - 1/14 } \\
\text { senvations: }\end{array}$ & & & & $\begin{array}{l}\text { /2014 - 6/2 } \\
\text { senvations: }\end{array}$ & & \\
\hline & Coefficient & Std. Error & Prob. & & Coefficient & Std. Error & Prob. & \\
\hline Indonesia & & & & & & & & \\
\hline$\beta_{1}$ & 0.0152 & 0.0124 & 0.2207 & & 0.0780 & 0.0171 & 0.0000 & $* * *$ \\
\hline$\beta_{2}$ & 0.0188 & 0.0190 & 0.3221 & & -0.0187 & 0.0239 & 0.4335 & \\
\hline$\beta_{3}$ & 0.9629 & 0.0219 & 0.0000 & $* * *$ & 0.9851 & 0.0316 & 0.0000 & $* * *$ \\
\hline & Iared: & 0.8298 & & & & 0.6808 & & \\
\hline & stat: & 1.9901 & & & & 1.8400 & & \\
\hline Korea & & & & & & & & \\
\hline$\beta_{1}$ & 0.1182 & 0.0172 & 0.0000 & $* * *$ & 0.1464 & 0.0180 & 0.0000 & $* * *$ \\
\hline$\beta_{2}$ & 0.0781 & 0.0262 & 0.0030 & $* * *$ & 0.0186 & 0.0251 & 0.4593 & \\
\hline$\beta_{3}$ & 0.7998 & 0.0303 & 0.0000 & $* * *$ & 0.6609 & 0.0332 & 0.0000 & $* * *$ \\
\hline & Iared: & 0.5694 & & & & 0.5308 & & \\
\hline & stat: & 2.3072 & & & & 2.0255 & & \\
\hline Malaysia & & & & & & & & \\
\hline$\beta_{1}$ & 0.0768 & 0.0143 & 0.0000 & $* * *$ & 0.1498 & 0.0200 & 0.0000 & $* * *$ \\
\hline$\beta_{2}$ & 0.0339 & 0.0218 & 0.1212 & & -0.0479 & 0.0279 & 0.0858 & $*$ \\
\hline$\beta_{3}$ & 0.9363 & 0.0252 & 0.0000 & $* * *$ & 0.9990 & 0.0369 & 0.0000 & $* * *$ \\
\hline & Iared: & 0.7325 & & & & 0.5564 & & \\
\hline & stat: & 2.1478 & & & & 1.9779 & & \\
\hline Philippines & & & & & & & & \\
\hline$\beta_{1}$ & 0.0690 & 0.0126 & 0.0000 & $* * *$ & 0.0452 & 0.0109 & 0.0000 & $* * *$ \\
\hline$\beta_{2}$ & 0.0198 & 0.0193 & 0.3055 & & 0.0302 & 0.0151 & 0.0459 & ** \\
\hline$\beta_{3}$ & 0.9148 & 0.0223 & 0.0000 & $* * *$ & 0.8759 & 0.0200 & 0.0000 & $* * *$ \\
\hline & Iared: & 0.7881 & & & & 0.8384 & & \\
\hline & stat: & 2.1095 & & & & 1.9394 & & \\
\hline Singapore & & & & & & & & \\
\hline$\beta_{1}$ & 0.0885 & 0.0123 & 0.0000 & $* * *$ & 0.0912 & 0.0120 & 0.0000 & $* * *$ \\
\hline$\beta_{2}$ & 0.0619 & 0.0188 & 0.0010 & $* * *$ & 0.0183 & 0.0167 & 0.2753 & \\
\hline$\beta_{3}$ & 0.7208 & 0.0218 & 0.0000 & $* * *$ & 0.6972 & 0.0222 & 0.0000 & $* * *$ \\
\hline & Iared: & 0.7590 & & & & 0.7728 & & \\
\hline & stat: & 2.3466 & & & & 2.1992 & & \\
\hline Thailand & & & & & & & & \\
\hline$\beta_{1}$ & 0.0787 & 0.0108 & 0.0000 & $* * *$ & 0.0552 & 0.0102 & 0.0000 & $* * *$ \\
\hline$\beta_{2}$ & 0.0047 & 0.0165 & 0.7759 & & 0.0086 & 0.0142 & 0.5476 & \\
\hline$\beta_{3}$ & 0.8571 & 0.0191 & 0.0000 & $* * *$ & 0.8093 & 0.0189 & 0.0000 & $* * *$ \\
\hline & Iared: & 0.8327 & & & & 0.8517 & & \\
\hline & stat: & 1.9069 & & & & 1.8396 & & \\
\hline
\end{tabular}

Note: $* * * * *$, and $*$ denote significant $1 \%, 5 \%, 10 \%$ level.

Note: Author's calculation 
Table 11. Variance Inflation Factor

\begin{tabular}{|r|r|r|r|r|r|}
\hline Variance Inflation Factor & & & \\
\hline CHF base & & Period 2 & Period 4 & Period 4a & Period 4b \\
\hline & $\beta 1$ & 24.90 & 23.06 & 37.53 & 14.77 \\
\hline$\beta 2$ & 1.82 & 1.67 & 1.84 & 1.48 \\
\hline & $\beta 3$ & 24.92 & 23.26 & 38.70 & 14.59 \\
\hline NZD base & & Period 2 & Period 4 & Period 4a & Period 4b \\
\hline & $\beta 1$ & 14.33 & 2.84 & 3.61 & 2.16 \\
\hline & $\beta 2$ & 20.74 & 3.49 & 4.74 & 2.46 \\
\hline$\beta 3$ & 3.53 & 1.41 & 1.63 & 1.22 \\
\hline
\end{tabular}


Table 12. Event Analysis

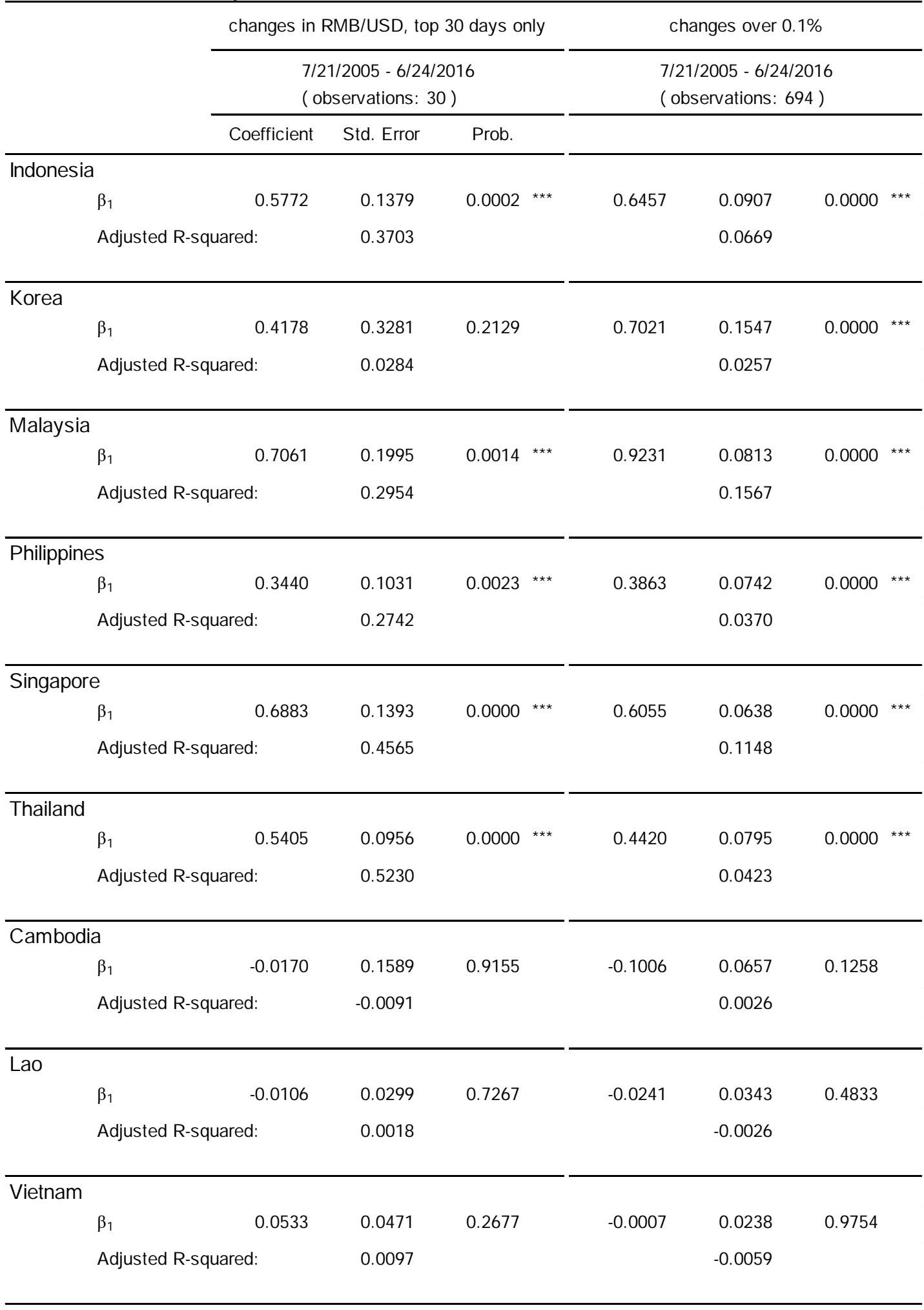

Note: $* * *, * *$, and $*$ denote significant $1 \%, 5 \%, 10 \%$ level.

Note: Author's calculation 
Figure 7. Growth in Currency Swap arrangements

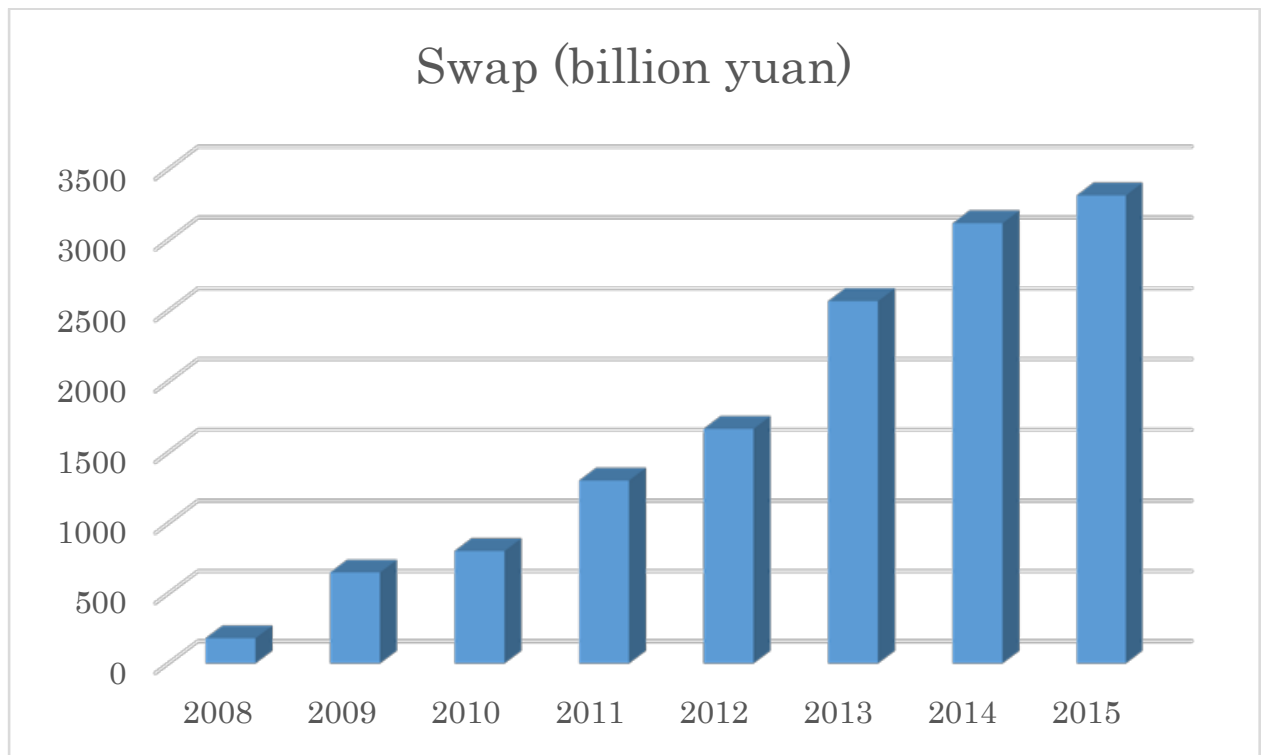

Source: Renmin University (2016) 
Figure 8. Foreign Reserves (COFER statistics)

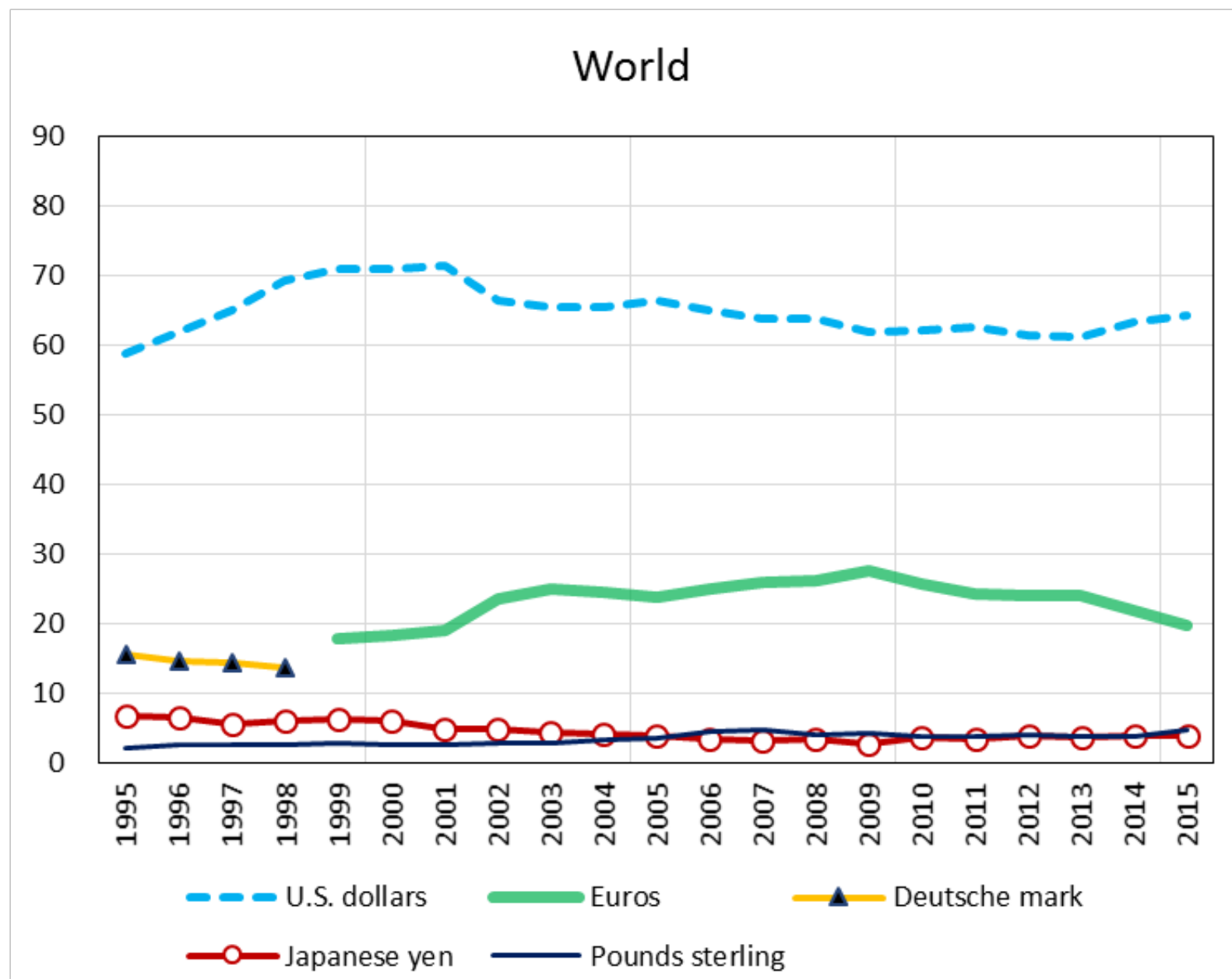

Source: IMF COFER statistics 
Table 13. SDR composition currencies and shares.

(a) Long-term changes

\begin{tabular}{|l|r|r|r|r|r|r|r|r|}
\hline & 1980 & 1985 & 1990 & 1995 & 2000 & 2005 & 2010 & 2015 \\
\hline US Dollar & 42 & 42 & 40 & 39 & 45 & 44 & 41.9 & 41.73 \\
\hline Euro & & & & & 29 & 34 & 37.4 & 30.93 \\
\hline German Mark & 19 & 19 & 21 & 21 & 1 & & & \\
\hline French Franc & 13 & 12 & 11 & 11 & & & & \\
\hline Japanese Yen & 13 & 15 & 17 & 18 & 15 & 11 & 9.4 & 8.33 \\
\hline British Pound & 13 & 12 & 11 & 11 & 11 & 11 & 11.3 & 8.09 \\
\hline Chinese Yuan & & & & & & & & 10.92 \\
\hline
\end{tabular}

Source: International Monetary Fund.

(b) Details of changes from 2010 to 2015

\begin{tabular}{|c|c|c|c|}
\hline SDR Basket & & 2010 standard & $\begin{array}{l}2015 \text { Reform } \\
\text { implemented October } 2016\end{array}$ \\
\hline $\begin{array}{l}\text { Determining } \\
\text { Factors }\end{array}$ & & $\begin{array}{c}\text { Export } 2 / 3 \\
\text { Foreign reserves: } 1 / 3\end{array}$ & $\begin{array}{c}\text { Exports } 50 \% ; \\
\text { Foreign Reserves } 16.7 \% \text {; } \\
\text { Foreign Exchange } \\
\text { Transactions } 16.7 \% \text {; } \\
\text { International Banking } \\
\text { Liability and International } \\
\text { Bond outstanding, } 16.7 \%\end{array}$ \\
\hline U.S. dollar & USD & 41.9 & 41.73 \\
\hline Euro & EUR & 37.4 & 30.93 \\
\hline Renminbi & RMB & & 10.92 \\
\hline Japanese yen & JPY & 9.4 & 8.33 \\
\hline British pound & GBP & 11.3 & 8.09 \\
\hline
\end{tabular}


Table 14. COFER vs. Special Survey

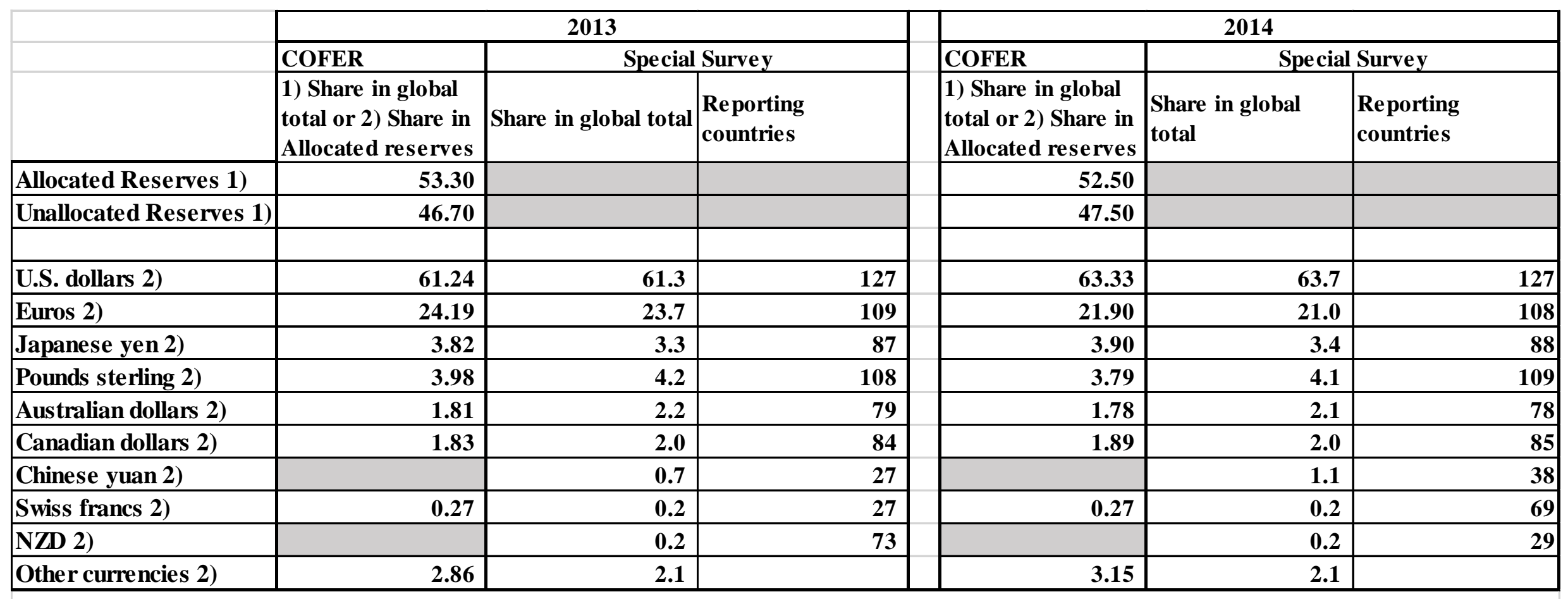

Source:IMF COFER statistics and IMF (2015a). 
Table 15: Ranking Summary for RMB

\begin{tabular}{|c|c|c|c|c|}
\hline RMB ranking & & & & \\
\hline Category & Month/Year & Ranked & Share & Source \\
\hline Swift world payment & 2016: June & 6 & $1.72 \%$ & SWIFT \\
\hline $\begin{array}{l}\text { Forex Market Turnover, } \\
\text { total }\end{array}$ & 2016: April & 8 & $2.0 \%$ & $\begin{array}{l}\text { BIS Triennial Survey } \\
\text { The original table shows " } 4.00 \% \text { " out of } 200 \%\end{array}$ \\
\hline $\begin{array}{l}\text { Forex Market Turnover, } \\
\text { spot }\end{array}$ & 2016: April & 7 & $2.0 \%$ & The original table shows " $4.01 \%$ " out of $200 \%$ \\
\hline $\begin{array}{l}\text { Forex Reserves } \\
\text { COFER }\end{array}$ & 2016 Q1 & $\begin{array}{l}\text { not in the } \\
\text { top } 7\end{array}$ & & IMF COFER \\
\hline $\begin{array}{l}\text { Forex Reserves } \\
\text { special survey }\end{array}$ & 2014 & 7 & $1.1 \%$ & IMF (2015a), p.12 \\
\hline SDR composition & 2016: October & 3 & $10.92 \%$ & IMF (2015b) \\
\hline $\begin{array}{l}\text { International Banking } \\
\text { Liabilities }\end{array}$ & 2015: Q2 & 5 & $1.8 \%$ & IMF (2015a), p.13 \\
\hline $\begin{array}{l}\text { International Debt } \\
\text { Securities, Outstanding }\end{array}$ & 2015: Q2 & 9 & $0.4 \%$ & IMF (2015a), p.14 \\
\hline $\begin{array}{l}\text { International Debt } \\
\text { Securities, Issuance }\end{array}$ & 2015: Jan - Jun & 6 & $1.0 \%$ & IMF (2015a), p.14 \\
\hline Cross-Border Payments & 2014: Q3-2015:Q & 8 & $1.1 \%$ & SWIFT and IMF (2015a), p.15 \\
\hline $\begin{array}{l}\text { Trade Finance (Letters of } \\
\text { Credit) }\end{array}$ & 2014: Q3-2015:Q & 3 & $3.4 \%$ & SWIFT and IMF (2015a), p.15 \\
\hline
\end{tabular}

